\title{
Observations on the Anatomy of Solenostelic Ferns.
}

\author{
Part II.
}

BY

\author{
D. T. GWYNNE-VAUGHAN, M.A., \\ Demonstrator in Botany at the University of Glasgow.
}

With Plates XXXII, XXXIV, and XXXV.

$\mathrm{T}$

HE terms used to indicate the different types of vascular arrangement in plants have recently become so numerous and varied that before going on to the descriptive part of this paper it is necessary to explain why some of those employed in it were chosen. So far as the Cyatheaceae and Polypodiaceae are concerned it is no longer advisable to make use of Van Tieghem's term 'polystely' for those cases in which the single central cylinder of the young plant becomes divided up into several separate portions, because it is now quite clear that none of the so-called 'steles' that result can properly be regarded as equivalent to the original central stele. It has therefore been decided to adopt the term 'dictyostele,' recently proposed by Brebner ${ }^{1}$, for the tubular network of vascular tissue that arises by the occurrence and overlapping of gaps in a solenostele. The separate portions into which

1 Brebner, On the anatomy of Danaea and other Marattiaceae, Annals of Botany, vol. xvi, no. lxiii, p. 523 , 1902 .

[Annals of Botany, Vol. XVII. No. LXVIII. September, 1903.] 
the original central stele has in this manner become broken up will be called 'meristeles.'

The most primitive type of vascular system that occurs in the Filicineae is probably the single protostelic central cylinder of the mature stem of Lygodium, the most important characteristic of which is that the continuity of the central xylem mass is not interrupted by the subsidence of the external tissues, cortical or vascular, at the departure of the leaf-traces. Such a structure has not yet been found in the mature stem of any of the Cyatheaceae or Polypodiaceae, although it is sometimes to be met with at the very base of the young plant. The solenostele holds an intermediate position between this simple protostelic type and the more complicated dictyostelic arrangements most frequently exhibited by these two orders, and it is chiefly due to this fact that the solenostele becomes a structure of particular interest.

The earliest reference to the solenostelic type of structure was made in $183^{8}$ by Robert Brown ${ }^{1}$, who noted the presence of a complete ring of vasa scalariformia in Polypodium Horsfieldii, R. Br. (Dipteris conjugata, Reinw.). A similar structure has since been recorded by various botanists in a large number of different Ferns, although many of their so-called 'pithcontaining wood-cylinders ' have proved upon investigation to be really dictyosteles and not solenosteles. Most of the examples included in this paper have already been mentioned at one time or another, and although most of the previous descriptions have been more or less inadequate or incorrect, those given by Karsten ${ }^{2}$ and Mettenius ${ }^{3}$ can hardly be improved upon. The true solenostele is not of very general occurrence, although it is to be met with in several different genera, e.g. Dicksonia, Davallia, Lindsaya, Hypolepis, Pteris,

1 Horsfield, Plantae Javanicae, p. 2.

${ }^{2}$ Die Vegetationsorgane der Palmen. Abhandl. d. K. Acad. d. Wissensch. z. Berlin, p. I86, 1847 .

3 Über den Bau von Angiopteris. Abhandl. d. K. Sächs. Gesellsch. d. Wissensch., Bd. vi, p. 53 I, I864. 
Pellaea, Polypodium, and Famesonia. However, in these and other genera (Cheilanthes, Nothochlaena, Adiantum, Gymnogramme, Antrophyum, and Vittaria) a number of transitional types related to the solenostele are to be found, which will also have to be taken into consideration. So many different species taken from several different genera have been examined that it is impossible to deal with them individually. It would also be very inconvenient to treat each genus separately, because their anatomical characteristics do not, for the most part, run parallel with their systematic position. Therefore, in the first part of this paper, where the general vascular arrangement in the stem is described, the plants will be dealt with in groups which will, as far as possible, lead up to the more interesting results that have come to light during the investigation. A few points of interest relating to the structure of the vascular bundles of the petiole, the lateral shoots, and the roots will be mentioned, and the histology of the vascular system will also be considered, but only in a very general manner.

\section{Typical Solenosteles.}

A perfectly solenostelic vascular system was found in the stems of all the species included in the following list ${ }^{1}$ : Davallia hirsuta, marginalis, strigosa, platyphylla, hirta, Speluncae, Novae-Zelandiae, Lindsaya retusa, Dicksonia apiifolia, cicutaria, scabra, punctiloba, davallioides, Pteris scaberula, incisa, ludens, Pellaea atropurpurea, falcata, and Famesonia imbricata. All these Ferns have a creeping, more or less dorsiventral rhizome with the leaves arranged in two rows on the upper surface, and their solenosteles differ from each other and from that of Loxsoma, as described in Part I of this paper ${ }^{2}$, in so slight a degree that the same description

${ }^{1}$ For the sake of uniformity the nomenclature of Hooker's 'Synopsis Filicum' will be adopted as far as possible throughont. It will therefore be unnecessary to give the authorities for the names, unless they are not recognized as such in the 'Synopsis Filicum.'

2 Annals of Botany, vol. xv, no. 1vii, I9or. 
will serve for them all. The gaps formed in the solenostele by the departure of the leaf-traces never overlap. The xylemring is surrounded, both externally and internally, by a complete ring of phloem and pericycle, and the whole is delimited from the ground-tissue on both sides by a wellmarked endodermis. The leaf-trace departs from the solenostele of the stem as a single continuous vascular strand, usually curved so that it has a section similar in form to a horse-shoe or an arch. This curved strand is so attached to the solenostele that its concavity faces the median dorsiventral plane of the rhizome, either directly, as in Dicksonia punctiloba (Pl. XXXIII, Fig. I), Pteris incisa, \&c., or else more or less obliquely, as in Dicksonia apiifolia (Fig. 2), Davállia Speluncae (Fig. 3), \&c. In Pteris ludens and Famesonia imbricata the leaf-trace faces directly towards the apex; a position it also occupies in Loxsoma (Part $\mathrm{I}^{1}$, Fig. 4 ); in this Fern, however, the leaves are inserted along the upper surface in a single median row. For some time before it actually departs, that portion of the solenostele destined to form the leaf-trace is usually well defined as a protrusion which is somewhat thinner than the rest of the vascular ring (Figs. 2 and 3 ). The leaf-gap generally closes up at the same time as the acroscopic flange of the leaf-trace departs, or immediately afterwards. It may, however, remain open for a short distance above the leaf, as in Davallia Speluncae (Fig. 3), Pteris hudens, Famesonia imbricata, and others. The free margin of the leaf-gap is usually of the same thickness as the rest of the solenostele, but in some cases it becomes more or less enlarged: Dicksonia apiifolia, cicutaria, Davallia hirta. The enlargement is entirely due to the increased thickness of the xylem-ring in this region; in the two Dicksonias it is often twice as thick as elsewhere in the stele, so that the free margin of the leaf-gap projects markedly towards within. This marginal thickening is a feature of considerable interest, and those Ferns in which it reaches a more conspicuous development will be treated separately later on. When 


\section{Anatomy of Solenostelic Ferns.}

lateral shoots are borne by any of the above Ferns they are always inserted upon the base of the petiole, and their vascular systems are joined on to one or the other margin of vascular strand of the petiole (cf. Figs. 4, 5, and 6).

A perfect solenostele is also present in the stem of Hypolepis tenuifolia, millefolium, distans, and repens, but certain additional peculiarities occur in relation to the insertion of the leaftrace which will require especial description. The stem is a dorsiventral rhizome, as in the Ferns mentioned above, with the leaves arranged in two rows upon the upper surface. The leaf-trace becomes definitely marked off from the rest of the solenostele some distance before it actually departs as such, and the gap formed by its departure runs forward a considerable distance before it is closed up again. The leaftrace consists of a single curved strand in all cases except in $H$. tenuifolia, where it departs as two separate pieces, and later on in the petiole breaks up into several. One or more lateral shoots are given off from the base of each leaf in all four species. If only one is present it always arises from the basiscopic margin of the leaf-trace, if there are two or more, then the lowest on the basiscopic side is always stronger and further developed than the others (Fig. 6). In order to form the vascular system of a lateral shoot the margin of the leaf-trace curls inwards on to itself, and the curved portion eventually separates off as a gutter-shaped stele which rapidly closes up into a complete cylinder.

Reference to Figs. 4, 5, and 6 will show how this takes place, and also how the presence of the lateral shoots affects the form of the leaf-trace and the manner of its departure: At the very base the leaf-trace is very irregular in form, and its concavity is directed towards the apex of the stem, but once it has become free from the steles of the lateral shoots it exhibits the customary form of an arch, the concavity of which faces the median dorsiventral plane of the rhizome.

The structure of the node in these Ferns is still further complicated by the appearance of certain small vascular strands which connect up the free margins of the leaf-trace, 


\section{Gwynne-Vaughan.-Observations on the}

shoot-stele, and stem-stele with each other. In my specimens two such strands were usually present. The most constant of these was one running from the free margin of the guttershaped stele of a lateral shoot to that margin of the leaf-trace from which the shoot in question arose ( $a$ in Figs. 4,5 , and 6). The other strand, which was sometimes wanting, ran either from the free margin of the gutter of the basiscopic shoot to the opposite (acroscopic) margin of the leaf-trace ( $b$ in Figs. 4 and 6), or it started from the free margin of the leaf-gap itself and ran to the acroscopic margin of the leaf-trace ( $c$ in Fig. 5).

A perfect solenostele of almost exactly the same nature as that described in the above species of Hypolepis was also found in Polypodium punctatum. The lateral shoots arose in the same way, and, what is even more interesting, the small additional strands in the neighbourhood of the leaf-gaps were also present. In my specimen they had the same position and course as those marked $a$ and $c$ in the diagrams of Hypolepis.

Several other cases of solenostely were met with in different plants, which possess special features of such importance that it will be more convenient to deal with them separately later on.

\section{TRANSITIONAL TyPES.}

Vascular systems were found in a large number of Ferns belonging to several different genera which seem to represent a series of stages transitional, or intermediate, between solenostely and dictyostely. The examination of these forms makes it quite clear that the dictyostely of the Cyatheaceae and Polypodiaceae is primarily due simply and solely to the overlapping of the leaf-gaps in a solenostele ; although it is not to be denied that gaps may sometimes occur in the vascular cylinder which are not in any way related to the insertion of the leaves. It appears also that two different factors may be concerned in bringing about this overlapping of the leaf-gaps. In the first place, it is evident that if the 
leaf-gaps remain open long enough after the departure of the leaf-trace they will eventually overlap; again, the same result will also be obtained if the leaves be crowded sufficiently close together, although the leaf-gaps may close up comparatively rapidly.

In some of the intermediate forms the leaf-gaps only overlap now and then, so that the stem, to a certain extent, still remains in a solenostelic condition. In others again the overlapping is more general, and a complete stelar cylinder is only to be found at rare intervals. It will therefore be understood that cases sometimes arise where it is impossible to say definitely of the vascular system of the plant as a whole that it is either solenostelic or dictyostelic.

The investigation of these forms shows that the distinction drawn by De Bary ${ }^{1}$ between the dorsiventral and the radial type of vascular arrangement in dictyostelic Ferns is one of considerable value, because it will be seen that the structural features of the two types depend upon the different methods by which they are derived from the solenostele.

The transition from solenostely to dictyostely in a dorsiventral rhizome with two rows of leaves, one on either side of the upper surface, will be first considered. A reference to the diagrams (Figs. 7 and 8 ) will show the effect of closely crowded leaves, or of long persisting leaf-gaps upon the solenostele. It is seen that the dorsal internodal portion of the solenostele has become so reduced that it is now no more than a mere strand running across between each leaf-insertion from one margin of the large ventral portion of the solenostele to the other. A structure such as this may be found in the rhizomes of Nothochlaena Marantae (Fig. 7), trichomanoides, ferruginea, Pellaea rotundifolia (Fig.8), andromedaefolia, Adiantum trapeziforme, Kaulfussii, and Gymnogramme vestita. A similar type appears also to be present in Antrophyum reticulatum, but it is a little exceptional and will be referred to again later on. Transverse sections of the stems of these Ferns will in most cases exhibit a single large gutter-shaped

1 Comparative Anatomy, pp. 284 and 287 (Engl. ed.). 
meristele, but in some a small additional dorsal one will also be present.

Bearing in mind the structure just described one is now in a position to understand the somewhat aberrant form of solenostely found in the dorsiventral Ferns Cheilanthes lendigera and microphylla. So far as the endodernis and pericycle are concerned each leaf-gap in the stele is closed up before the next above is formed, but the leaf-gap in the xylem-ring remains open until it overlaps the gap formed in the xylem by the departure of the leaf-trace next above. In this manner a small separate xylem-strand is produced within the stele which crosses over between each leaf-insertion from one side of the open xylem-ring to the other; having precisely the same course and origin as the free dorsal meristele in the forms described above.

In the more perfectly dictyostelic Ferns the dorsiventral type of vascular arrangement becomes much more complicated, but, in most cases, the manner of its origin from the solenostele is essentially similar to that already described, although it may differ considerably in detail. For instance, in Asplenium scandens the internodes are long, and the course of the dorsal meristele as it runs across from one side of the ventral portion of the solenostele to the other is a very oblique one; moreover, since the two rows of leaves are on exactly opposite sides of the stem, the dorsal meristele is almost as large as the ventral. In a dissection of the stem, therefore, two fairly large meristeles are to be found, very similar to each other in form and size, and between each two leaf-insertions the dorsal meristele is seen to cross slowly over from one side of the ventral meristele to the other.

If the dorsal meristele were to pursue a straight course, and instead of coming into bodily contact itself with the ventral meristele, as in Asplenium scandens and the cases mentioned above (Figs. 7 and 8), it were to keep up its connexion with it at the same points as before by means of short transverse strands or sutures, a structure would then result essentially 
similar to that described and figured by Mettenius ${ }^{1}$ and De Bary (loc. cit.) in several different dorsiventral Ferns. All the Davallias of the section Humata that were examined belong to this type, and also most of those belonging to the sections Eudavallia and Leucostegia. In some of these Ferns, however, the actual state of affairs is a little obscured by the fact that several separate leaf-traces are given off to each leaf, which run forward for some distance in the ground-tissue of the stem before they turn out into the petiole, also the two meristeles of the stem are often so similar to these in form and size that they are scarcely to be distinguished from them.

Attention should also be drawn at this point to the vascular arrangement described by Mettenius (loc. cit., p. 552) in a number of dorsiventral Ferns, of which Platycerium alcicorne may be quoted as an example. In these the dorsal meristele seems to be present as usual, but the ventral one appears to be broken up into an irregular meshwork of strands, the gaps in which bear no relation whatever to the leaf-insertion.

In Ferns which have their leaves arranged radially in several rows all round a prostrate or an erect stem three or more leaf-gaps usually overlap at the same level, and the solenostele is broken up into just as many more or less equivalent meristeles arranged in a ring around the axis.

If the structure is still but little removed from solenostely it may happen that two leaf-gaps only overlap at any one level, and then the vascular arrangement, when seen in transverse section, generally consists of a large gutter-shaped meristele with another small one lying across its opening (Figs. 9 and 10). Although this structure is very similar in appearance to that presented by the simpler forms of the dorsiventral type, it is really to be regarded as quite distinct, because the relative positions of the two steles change in accordance with the radial arrangement of the leaves. The following Ferns were found to be radially dictyostelic, but still remain very close to solenostely: Dicksonia Barometz (Fig. I7), Pteris tremula, cretica, flabellata, heterophylla

1. c., Taf. vii, viii.

3 B 2 
pellucida, Taenitis blechnoides, Gymnogramme calomelanos (Fig. 9), Hemionitis palmata, Adiantum lunulatum, Lomaria semicordata (Plagiogyria biserrata, Met.) (Fig. IO). No particular form of leaf-trace is especially related to the simpler intermediate forms of dictyostely, either dorsiventral or radial. However, it generally consists of a single strand, as in Nothochlaena Marantae (Fig. 7) and Pteris tremula, or else it is divided into two separate portions, as in Adiantum trapeziforme and Gymnogramme calomelanos (Fig. 9).

Whenever more than two rows of leaves are found upon the stem of a Fern they are nearly always arranged radially all round the axis, even though it may be a creeping or prostrate rhizome. There are, however, a few in which they are inserted in several rows all upon the upper surface, and in these the rhizome is dorsiventral in structure, e. g. Pellaea cordata. It seems probable that they originally belonged to the radial type, and have become dorsiventral in a secondary manner in consequence of the prostration of the stem. It is also possible that they have been derived from a dorsiventral type with two rows of leaves by the intercalation of additional leaves between those already present. However, their anatomy has not yet been thoroughly investigated, and the question must be left open.

\section{Solenosteles with Internal Accessory Vascular STRANDS.}

Attention has already been drawn to the fact that the free margin of the leaf-gap in Dicksonia apiifolia and other solenostelic Ferns is considerably thicker than the rest of the solenostele, owing to an increase in the amount of xylem present at that point. In Dicksonia adiantoides this feature becomes so conspicuous and important that it requires especial description; particularly so because it appears to give an explanation of certain complex modifications of the vascular system that occur in a number of other Ferns. Dicksonia adiantoides has a dorsiventral rhizome with leaves in two rows on the upper surface, and a perfectly solenostelic vas- 
cular system. The leaf-trace consists of a single curved strand inserted so that its concavity faces the median dorsiventral plane of the rhizome, and the leaf-gap closes up at the same time as the acroscopic flange of the leaf-trace departs. The enlargement of the leaf-gap margin is so pronounced that it projects markedly towards the interior, and, what is more important, this projection is not confined to the limits of the open leaf-gap, as in the previous examples, but is continued as a ridge upon the internal surface of the solenostele throughout the whole length of the internode, running from one leaf-gap margin to the other (Fig. II). In the immediate neighbourhood of the leaf-gap the additional xylem-elements that cause the internal projection of the margin are in more or less complete continuity with the rest of the xylem-ring, just as in Dicksonia apiifolia, \&c., but in the internodes they become separated off as a distinct strand (Fig. I2), which may even be surrounded by a phloemring of its own distinct from that of the solenostele. This separate strand of xylem generally attains its greatest independence in the upper part of the internode, and is most closely fused with the xylem-ring of the solenostele towards the top of the leaf-gap. In my specimens the separate strand of xylem never became free from the endodermis and pericycle of the solenostele, but in a stout example it seems probable that along part of its course it may become completely isolated in the central parenchyma. The protoxylemelements of the solenostele are located in definite endarch or mesarch strands; a similar protoxylem-group is sometimes to be found in the internal xylem-strand (Fig. I2).

The insertion of the leaf-trace in this Fern is further complicated by the presence of lateral shoots and of one or two small vascular strands which run across the leaf-gap very much in the same way as those already described in Hypolepis. In this case they start from the internal surface, or from the basiscopic margin of the leaf-trace (Fig. II), and run forwards to the free margin of the leaf-gap. The marginal thickening and the transverse strands were found at nearly all the leaf- 
gaps, but occasionally, both in the main axis and in the lateral shoots, one or the other, or even both of these features may be wanting.

Seward and Dale ${ }^{1}$ have described a thickening of the margins of the leaf-gaps in Dipteris conjugata (Reinw.) which should probably be regarded as of the same nature as that in Dicksonia adiantoides, only a step more advanced. For in this case it appears that the free xylem-strand has almost separated off from the solenostele altogether, being connected with it only at two points, between which a tongue of groundtissue has inserted itself.

From the description given by Boodle ${ }^{2}$ it appears that a structure very similar to this is also to be found at the margin of the leaf-gaps of Gleichenia pectinata, and it is suggested that here again we have to deal with the same phenomenon as in Dipteris conjugata and Dicksonia adiantoides. One point of difference, however, is to be noted in the two last cases, which is that both flanks of horse-shoeshaped leaf-trace depart at the same time, and both sides of the leaf-gap are similarly thickened.

Before going on to describe the internal vascular strands that occur in the stem of Dicksonia rubiginosa it is necessary to point out certain very exceptional features that are also presented by the ordinary vascular cylinder of this plant. The habit of the rhizome and the insertion of the leaf-traces are essentially the same as in Dicksonia adiantoides. The leaf-gaps close up directly after the leaf-trace departs (Fig. I3), but nevertheless the vascular system cannot be regarded as a solenostele, because in addition to the leaf-gaps other lacunae occur in the stelar cylinder which have no relation to the leafinsertion whatever. These lacunae occur somewhat irregularly, but chiefly along two lines on opposite sides of the creeping rhizome. They are sometimes comparatively short, but more

\footnotetext{
1 Structure and Affinities of Dipteris, \&c., Phil. Trans., Series B, vol. cxciv, p. 499, and Fig. 4, 1901.

2 On the Anatomy of the Gleicheniaceae, Annals of Botany, vol. xv, no. 1x, p. 730,1901 .
} 
often they form long splits interrupted by small meristeles passing across the lacuna from one side to the other. Although a completely closed vascular ring is sometimes to be met with in transverse sections of the internode, the most frequent appearance is that of two large curved meristeles, one dorsal and one ventral, with or without one or two smaller ones lying between their margins. In this plant, therefore, an entirely exceptional kind of dictyostely has been attained without relation to the overlapping of the leaf-gaps; indeed so far as that is concerned the vascular structure may still be regarded as solenostelic. So far as I am aware, in this respect Dicksonia mubiginosa stands unique among the Ferns.

The accessory vascular strands found within the ordinary stelar cylinder vary in number from point to point. There were never more than three present in my specimen, and sometimes they all fused up to a single large curved strand. In their course through the internode they may branch and anastomose with each other, but they never come into contact with the internal surface of the ordinary stelar cylinder except in the neighbourhood of the nodes. At each node a single internal strand approaches the free margin of the leaf-gap, and gradually fuses with it until the two xylems are perfectly continuous, presenting an appearance exactly as in Dicksonia adiantoides. As soon as the leaf-trace has departed it separates off again and passes on as a free internal strand into the internode above. One internal strand at least was present in all parts of the specimen examined, even at the base of the narrow lateral shoots. Distinct mesarch protoxylem groups are to be found in them, which, however, do not appear to be in any way related to those of the leaf-trace. In this plant, again, the vascular systems of lateral shoots are usually to be found departing from the margins of the petiolar strand, and, as in Dicksonia adiantoides, small vascular strands are sometimes to be met with which run forward from the internal surface of the leaf-trace to the free margin of the leaf-gap.

A still more conspicuous system of internal vascular strands 


\section{Greynne-Vaughan.-Observations on the}

is to be found in the stem of Pteris elata ${ }^{1}$ which is an erect or oblique rhizome with the leaves arranged radially all round. The vascular system is perfectly solenostelic, and the leaf-gap closes up immediately after the departure of the leaf-trace. The curved leaf-traces are inserted with their concavities facing directly towards the apex, which, moreover, appears to be always the case in all Ferns in which the stem grows erect. The appearance of the internal vascular system will vary according to the dimensions of the plant, and to the position of the section relative to the nodes (Fig. I4). In a rhizome of average thickness the internal system usually has the form of a large gutter-shaped strand or of a completely closed cylinder, the latter being generally present for some distance below each of the nodes. As the leaf-gap is approached from below a fairly large flat strand is seen to separate off from the internal vascular cylinder, which, travelling forwards and outwards, ends by fusing completely and finally with the anterior margin of the leaf-gap in the outer solenostele; just as the latter becomes closed up again. The lacuna thus produced in the internal vascular cylinder converts it into a gutter which, however, gradually closes up in the internode above, so that a complete cylinder is again formed, usually for some distance before the next leaf-insertion is reached. Sometimes, on the other hand, two such gaps in the internal vascular system may overlap, so that two separate internal strands are occasionally to be met with.

In large and especially well-grown rhizomes a second internal vascular system is to be found lying within the first. It is not, however, very highly developed, but consists of a single small free rounded strand. This central strand fuses with the margin of each of the lacunae in the first internal cylinder, but usually separates off again after a little while. In fact, it behaves towards the first internal vascular system in exactly the same way as the internal vascular strand of Dicksonia rubiginosa behaves to the ordinary stelar cylinder.

1 Pteris elata, var. Karsteniana, Kz., a variety not mentioned by Hooker, was the plant actually investigated. 
More rarely, it is not the central strand itself that goes to fuse with the margin of the lacunae, but a branch given off from it; in which case it terminates there and does not separate off again. Even in rhizomes of medium size indications of this second internal system are not wanting, for it is often to be observed that one of the margins of the lacunae in the first internal vascular cylinder is considerably thickened, and projects inwards in a manner similar to the margins of the leaf-gaps in the solenostele of Dicksonia adiantoides. The solenostele at the base of the lateral shoots (which arise from about the middle of the back of the petiolar strand, and not from its margin) is perfectly typical and without any internal strands. I have no doubt that a series of stages intermediate between this and the complex structures described above are to be found in weak rhizomes, or, at any rate, in the young plant.

Judging from the description given by Seward ${ }^{1}$ the vascular system of Matonia pectinata seems to be essentially similar to that of Pteris elata, both as regards the arrangement of the internal accessory strands, and also in their relation to the leaf-insertion. Miss Wigglesworth's ${ }^{2}$ account of the same plant serves to strengthen this opinion, although it appears that in her specimen the complexity of the internal systems is carried a step further still. For the third and most central system, which in Pteris elata consists of a small rounded strand only, is represented by a large gutter-shaped strand, or even by a completely closed cylinder.

From the description of Dicksonia Plumieri (Saccoloma adiantoides, $\mathrm{Sw}$.) given by Mettenius ${ }^{3}$ it is clear that in this plant again the vascular system is constructed upon exactly the same plan, and, moreover, it appears that a still higher degree of complexity is reached than in the Matonia of

1 The Structure and Affinities of Matonia pectinata, Phil. Trans. Roy. Soc., Lond., Series B, vol. cxci, p. I7 I, I899.

2 Notes on the rhizome of Matonia pectinata, The New Phytologist, vol. i, no. vii, p. 157,1902 .

s. c., p. 53 I. 
Miss Wigglesworth. For not only are there two concentric vascular cylinders lying within the ordinary solenostele, but a small central strand is present in addition, which may be regarded as an indication of a third.

It is evident that in all these cases the ordinary typical vascular cylinder is represented by the outermost vascular system. The internal vascular system is an accessory development, and from the consideration of the facts brought forward above it appears that, even in its most complex form, it is to be derived from the ordinary stelar cylinder by the progressive elaboration of a local thickening of the xylemring at the leaf-gap margin. The initial stage of such a development would be a simple marginal thickening something like that in Dicksonia apiifolia. The first step in advance would be the further development of this thickening into an internal ridge resembling that in Dicksonia adiantoides. Very little is wanting to separate off this ridge so as to give rise to a free internal strand similar to those in Dicksonia rubiginosa. The internal strand might then become converted into a more or less closed cylinder, like that found in Pteris elata, in two different ways : either by enlarging and at the same time curving round so that its two ends eventually meet, or as it enlarged it might also branch, and the branches eventually fuse up into a ring. It is difficult to decide which of these two methods is the more probable, indeed, it is possible that both may occur. If the same series of changes were to take place in the first internal ring a second would be produced, and thus again a third, one lying within the other, as exemplified by Pteris elata and Matonia pectinata.

It must at once be understood that the order in which these Ferns have been placed in order to illustrate this theory is not intended to represent a phylogenetic series. All that it is necessary to assume is that their relationship is sufficiently close for the various modifications of structure that they present to be taken in explanation of one another. According to the theory outlined above a strong distinction must be drawn between the internal vascular cylinders and the original 
external one, because the former are not only different in origin, but also later in development. In this it differs essentially from the suggestion put forward by Seward ${ }^{1}$ and Boodle $^{2}$, according to which it would appear that the internal vascular cylinder was split off as a whole from the original solenostele. It is to be regretted that young plants of none of these Ferns were available for examination, for no doubt they would provide much valuable information upon this question.

\section{The Cyatheaceae.}

The first observations upon the anatomy of this order were made about a hundred years ago by Plumier, who describes the appearance of the cut end of a stem of a Cyathea. The history of the subsequent attempts to arrive at a more satisfactory knowledge of their structure is unusually interesting, in that it discloses how the successive results were damaged and impeded by the interference of preconceived ideas based upon currently accepted theories. For instance, it is evident that the opinions held by most of the earlier anatomists upon the nature of the Fern stem in general were really the outcome of a statement made by Cesalpino so long ago as $1583^{3}$. Having first come to the conclusion that Ferns do not possess true seeds, Cesalpino proceeded to deduce the fact that they cannot possess true stems either. Hence, in the earlier part of the last century, we find that Brisseau-Mirbel ${ }^{4}$, Link $^{5}$ and Hanstein ${ }^{6}$ all firmly refuse to recognize a true stem in the Ferns, insisting that their caudex is merely a sympodium of leaf-bases. Indeed, the authority of Cesalpino does not seem to have lost all its influence even

\footnotetext{
1 The structure and affinities of Matonia pectinata, Phil. Trans. Roy. Soc. Lond., Series B, vol. cxci, p. I8o, 1899 .

${ }^{2}$ On the anatomy of the Gleicheniaceae, 1. c., p. 739.

${ }^{3}$ De plantis, lib, I, cap. I4.

- Élémens de botanique, vol. i, p. I22, I815.

${ }^{5}$ Einige Bemerkungen über den inneren Bau der holzigen Farnkräuter, Linnaea, p. 414, I826; also, Über den Bau der Farnkräuter, Abhandl. d. K. Acad. d. Wissensch. z. Berlin, p. $375, \mathrm{x} 834$, and $\mathrm{I} 835$, p. 82.

${ }_{6}^{6}$ Plantarum vascularium folia, caulis, \&c., Linnaea, p. $65,1848$.
} 


\section{Groynne-Vaughan.-Observations on the}

at the present time. For his conclusion lies essentially at the base of the various theories of 'phytons,' 'rejuvenescence,' and 'segmentation' that have been advanced by Gaudichaud, C. H. Schultz, Delpino, and others. The most recent modification of these theories is that set forth by Celakovský ${ }^{1}$ in his paper upon the segmentation of the stem. He also arrives at the same conclusion as Cesalpino, from very different premises, but by an analogous process of deduction. So far as the Ferns are concerned, it is fairly clear that any apparent segmentation that may occur in this group is to be regarded as a late development rather than a primitive feature, because it is becoming more and more probable that the dictyostelic species, in which the so-called segmentation is most obvious, are to be derived from solenostelic forms, and these in turn from forms with a solid central cylinder. That is to say, so far as the structure of the stem is concerned, there is less indication of segmentation in the primitive types than in the more advanced. Von Mohl ${ }^{2}$, with his habitual freedom from external influences, was the first to establish the cauline nature of the vascular system of the Tree-fern stem; the leaves being supplied by branches given off from the stem system. He admitted that the vascular strands in the 'pith' of the stem ran out directly through the leaf-gap into the centre of the petiole, but in spite of this, he utterly rejected the comparison of the Tree-ferns with the Monocotyledons which had hitherto been advanced with enthusiasm by Link and others. From now on the controversy settled upon the nature and course of these central strands of the leaf-trace. Karsten ${ }^{3}$, who next investigated them, observed that their course in the stem was similar to that of the central vascular bundles of a Palm, and in consequence revived the Monocotyledonous comparison, rendering it so much support that it continued to exercise

1 Die Gliederung der Kaulome, Bot. Zeit., Bd. lix, p. 79, 1901 .

2 Über den Bau des Stammes der Baumfarne, Vermischte Schriften, p. 108. Tübingen, 1845 . First published in Martius' 'Icones plantarum cryptogamicarum Braziliae,' 1833 .

3 Die Vegetationsorgane der Palmen, Abhandl. d. K. Acad. d. Wissensch. z. Berlin, p. 186, i 847 . 
a marked influence upon many subsequent investigations. Stenzel ${ }^{1}$, however, was entirely unaffected by it, and was the first to declare that even the central strands of the stem were cauline, although he admits that branches are given off from them which run out into the centre of the petiole. The Monocotyledonous comparison was also rejected by Mettenius ${ }^{2}$, although he still describes the central strands of the stem as running out direct into the petiole, sending branches to the margin of the leaf-gap as they pass through. The point was carefully reinvestigated by Trécul $^{3}$ in 1869 , who reverts to the opinion of Stenzel, and concludes that none of the central strands of the stem pass out as such into the petiole, and that therefore all the vascular bundles of the leaf-scar arise from the margin of the leaf-gap. De Bary, in his text-book (1. c., p. 29I), follows Mettenius, so that the question may be regarded as still an open one.

Cyathea Brunonis, a Tree-fern with comparatively simple once-pinnate leaves, was examined by me, and will serve as a good example in which to describe the relations that exist between the internal accessory strands and the leaf-traces. In this plant the ordinary stelar cylinder is a dictyostele consisting of two or three large band-shaped meristeles separated by relatively small leaf-gaps. A large number of separate leaf-traces arise from the outwardly turned margin of each leaf-gap, and these are so arranged in the petiole that a figure is produced in transverse section easily recognizable as a modification of the outline given by the gutter-shaped trace so often met with in Fern petioles. In this case, however, the margins of the gutter are strongly curved towards within, and there is also a deep tuck or fold along each of its sides (Fig. I5). In consequence of this, certain of the petiolar strands come to lie some distance within the others, and these are the central strands, the origin and

1 Über Verjüngungserscheinungen bei den Farnen, Verhandl. d. Deutsch. Acad. d. Naturforsch., Bd. xxviii, p. I8, I86I.

1. c., p. 525 .

${ }^{3}$ Remarques sur la position des trachées dans les Fougères, Ann. des Sc. Nat., $5^{\text {e }}$ sér., vol. xii, p. 274,1869 . 
course of which is under dispute. To return to the stem; the internal strands are small and round, and about twenty or thirty of them are scattered in the ground-tissue within the ordinary stelar cylinder. At each leaf-insertion four of them approach the margin of the leaf-gap and join on to it exactly at the points of departure of certain of the leaf-traces (Figs. 15 and 16 ). The first pair join on to the traces $a, a$, the next pair divide each into two branches, which join on to the traces $b, b$ and $c, c$, respectively. In their course from the leaf-gap margin down the stem the internal strands run first of all towards the centre, and then, turning more directly downwards, they travel obliquely towards without, diminishing as they do so, and finally ending blindly without coming into contact with the external stelar cylinder. The leaf-trace protoxylems are all endarch, but they gradually become mesarch as they pass down the stem; those of the leaf-traces that abut upon internal strands are continued down the internal strands; those of the others run down the margin of the leaf-gap, joining on to each other as they do so, and rapidly disappearing after the leaf-gap has closed. In other species ( $C$. arborea and $C$. glauca) Trécul has shown that matters are much more complicated and obscure, because the number of internal steles related to each leaf-insertion is greater, and those leaf-traces that abut upon the internal strands often stand away from the leaf-gap margin, remaining connected with it only by a short horizontal strand, or they may even be altogether free from it.

Considerable light is thrown upon the nature of the central strands of the petiole by the structure of Dicksonia Barometz. There are no internal vascular strands at all in the stem of this Fern, but only the ordinary stelar cylinder. The leaf-gaps are very small and close up rapidly, nevertheless they occasionally overlap each other, and therefore the structure must be regarded as dictyostelic, although it is very near solenostely. The leaf-trace departs as a single piece, but sooner or later it breaks up into a large number of separate strands. The point at which the disintegration 


\section{Anatomy of Solenostelic Ferns.}

takes place varies from one leaf to another; sometimes it breaks up almost immediately upon its departure from the stelar cylinder of the stem, and sometimes not until it has reached the free petiole (Fig. 17). While the leaf-trace remains a single continuous strand it has the form of a gutter with deeply incurved margins and a fold along each of its sides. After it has become broken up into separate portions these still keep the same conformation, so that some of the strands, chiefly those of the incurved margins, come to occupy a central position exactly as they do in Cyathea Brunonis. In this case, however, all the separate strands clearly arise from the leaf-gap margin, and from the leaf-gap margin only.

It may be mentioned in passing that lateral shoots are of frequent occurrence in Dicksonia Barometz, and like those of Pteris elata they arise not from the margin but from the back of the leaf-trace, just before it begins to break up. Sometimes two may arise upon the same petiole.

These observations all tend to prove that Trécul was quite correct in maintaining that the internal strands of the stem are strictly and essentially cauline, and this being granted, the idea is at once suggested that they are essentially similar in nature and origin to those of Dicksonia rubiginosa, Pteris elata, \&c. It will be seen that this suggestion receives strong support from the manner in which the internal strands first appear in the young plant of Alsophila excelsa.

I have been able to examine a number of young plants of Alsophila excelsa that were grown from the spore, and since the vascular system of the young plant of the Cyatheaceae has not yet been dealt with in detail, it is perhaps advisable to describe their structure at some length. Although the course of the development of the vascular system was practically the same in all the specimens examined, yet the rapidity with which the different stages are passed through varies considerably according to the conditions of growth. It must be understood, therefore, that the description given here is a more or less generalized one, and that it must not 
be expected to hold good rigidly from leaf to leaf in every specimen. This statement applies in particular to the diagram given in illustration (Fig. I 8). With this reservation, however, it is believed that the diagram will serve to represent the course of development of the vascular system, not only in the Cyatheaceae, but also in most of the solenostelic and dictyostelic Ferns up to the particular stage that they retain when mature.

The young plant of Alsophila excelsa has its leaves arranged radially all round the axis, and it probably grew erect. At the very base of the stem the single central cylinder possesses a small central strand of xylem, usually with a few xylem-parenchyma cells intervening between the tracheides. The first leaf-trace may depart without in any way altering the structure of this stele or of its xylem-strand, but usually the phloem on the adaxial surface of the leaf-trace is prolonged a short distance downwards into the substance of the central xylem. At the departure of the subsequent leaves this feature is much more pronounced, and the phloem thus decurrent runs down through the whole length of the internode to meet with that decurrent from the leaf below. In the second leaf, however, it often falls short of the point of departure of the first leaf and ends blindly in the internode. From this point, therefore, up to the third or fourth leaf the centre of the xylem-strand is occupied by a core of phloem. At the departure of about the third or fourth leaf the pericycle follows the phloem down into the internode below, so that a few pericyclic cells are now to be found in the centre of the core of phloem. At the fifth leaf (or sometimes at the fourth) the endodermis also is decurrent, giving rise at first to a few cells only in the centre of the pericycle which usually disappear before the node below is reached. Higher up it is continuous from node to node, and surrounds a progressively increasing amount of ground-tissue which is now decurrent with it. The vascular system has, in fact, at length become a solenostele. This stage, however, does not last long, for the leaf-gaps begin to overlap after the departure of about the eighth leaf, 
and above this point it becomes more and more dictyostelic, although at first a complete vascular ring is occasionally to be met with. The leaf-trace of the first five or six leaves consists of a single curved strand. Above this point two or three separate strands are given off to each leaf, and at about the tenth leaf four such strands are present, two arising from each side of the leaf-gap.

The first indication of internal steles that occur in the mature plant is to be found at about the tenth leaf. Just below one or both of the two upper (adaxial) traces of this leaf the xylem of the stem-stele is seen to project slightly towards within, so as to form a small ridge on its internal surface, which is often continued as such for some distance down the stem. Sometimes, however, it separates off completely so as to produce a small xylem-strand lying free within the phloem of the stele, which either ends blindly below, or eventually fuses up again with the main xylem-strand. These free xylem-strands are always present at the subsequent leaf-gaps, and although still remaining enclosed by the same endodermis, they become more and more distinct from the main xylem-strand of the stele. Later on they may even separate off from the stele altogether in the upper part of their course, only fusing with it again at a point lower down. The separation of the small xylem-strands from the main stele finally becomes complete throughout, and from their starting-point they run as small independent vascular strands ending blindly in the central ground-tissue, having no further communication with the main stele, except sometimes by a small branch near their point of origin.

It seems; therefore, that the internal vascular strands of Alsophila excelsa owe their existence to the same initial phenomena as do those of Dicksonia rubiginosa. That is to say, they are probably derived from the elaboration of a local thickening of the xylem-ring at the margins of the leaf-gaps in the ordinary stelar cylinder. The earlier stages of their development also proceed along essentially the same lines, although it is to be admitted that there are certain marked 


\section{Groynne-Vaughan.-Observations on the}

differences. Thus in Alsophila excelsa the internal strands of one leaf-gap are not related to any of the other leaf-gaps, nor are the internal strands of succeeding leaf-gaps in any way joined up or connected with one another. It should also be noted that in this plant the internal strands do not appear at all until the ordinary stelar cylinder has become more or less dictyostelic.

The real nature of the accessory cortical strands that occur in certain Cyatheaceae (Cyathea arborea, Alsophila armata, \&c.) is not as yet known with certainty. Two concentric rings of vascular strands are also present in the stems of Acrosticum scandens and $A$. tenuifolium (Lomaria fraxinifolia). According to Bertrand and Cornaille ${ }^{1}$ the leaf-traces arise from both of these two rings, but which of the two is to be regarded as the typical stelar cylinder has not yet been decided.

In the stem of Davallia immersa, again, two concentric series of vascular strands are present. The central ring alone gives off the leaf-traces, and probably represents the typical stelar cylinder. My material was not sufficient to determine the nature of the small peripheral strands. It is possible, however, that they are merely root-steles that run forwards for a long distance in the ground-tissue of the stem before turning outwards.

\section{Davallia aCUleata AND D. PinNata.}

The stem of Davallia aculeata, like those of the other solenostelic Davallias, is a dorsiventral rhizome with the leaves inserted in two rows upon the upper surface, but the solenostele itself differs so much in structure from those already described that it deserves especial mention. Instead of surrounding a central mass of ground-tissue as a hollow vascular cylinder, the wall of which is of the same breadth throughout as in the previous examples, the ventral region of the soleno-

1 Etude sur quelques caractéristiques de la structure des Filicinées actuelles. Mémoires de l'Université de Lille, tom. x, no. 29, p. I36, 1902. 
stele in $D$. aculeata is more than twice as broad as the dorsal region. In consequence of this the enclosed ground-tissue is displaced so as to occupy an excentric position near the dorsal surface (Fig. I9). The extra breadth of the ventral half of the solenostele is entirely due to the increased amount of xylem present in that region, because the sheath of phloem and pericycle is of approximately even thickness throughout, both on the inside and on the outside of the stele (Fig. 20). No definite protophloem is to be made out on the inside of the stele, although it forms a fairly distinct layer on the outside. The absence of an internal protophloem is, however, sometimes to be observed even in typical solenosteles, e.g. Lindsaya retusa. The leaf-trace departs from the narrow dorsal region of the solenostele as a single curved strand with its concavity directed toward the median dorsiventral plane of the rhizome. In passing outwards it gradually loses its curvature, and in the free petiole has the form of an equilateral triangle with rounded angles and sides; the xylem-strand, however, still remains $\mathrm{V}$-shaped. The leaf-gap is very small and is closed up at the same time as the acroscopic margin of the leaf-trace is set free.

In Davallia pinnata the habit of the stem and the insertion of the leaves is exactly the same as in D.aculeata. The appearance presented by the vascular system also, at least in sections taken just below a leaf-insertion, is very similar in both. It has at these points the form of a hollow vascular cylinder, the wall of which is very much broader in the ventral region than it is in the dorsal, and the ground-tissue enclosed within the stele is displaced, as in D. aculeata, so as to lie excentrically near the dorsal side (Fig. 2I). On the other hand, the extra breadth of the ventral half of the vascular ring in $D$. pinnata is not entirely due to the xylem alone as it was in D. aculeata. The internal phloem also takes part in its production, there being a much greater quantity of this tissue on the ventral side of the enclosed ground-tissue than on the dorsal (Fig. 22). The anatomy of this plant has already been described by 


\section{Greynne-Vaughan.-Observations on the}

Tansley and Lulham ${ }^{1}$, and the following observations confirm their account. The leaf-trace departs as a single strongly curved strand with the concavity, as usual, facing towards the median dorsiventral plane of the rhizome. The leaf-gap closes up at the same time as, or even slightly before, the leaftrace is quite free. The sclerenchymatous ground-tissue lying in the concavity of the leaf-trace passes down with it into the substance of the stem-stele. In this manner it produces the leaf-gap itself, and also accounts for the stout strand of sclerenchyma, surrounded by endodermis and pericycle, that lies within the stele, near its dorsal side, in regions just below the nodes. If the strand of ground-tissue thus enclosed be followed downwards through the internode to the node below, it is seen to diminish gradually in size until finally it disappears altogether, usually a short distance before the leafgap next below is reached. So that in the lower part of each internode the whole space within the xylem is occupied by internal phloem alone (Fig. 2I). Occasionally, however, the strand of ground-tissue may persist until that decurrent through the leaf-gap next below is also enclosed in the stele. In the specimens examined the ground-tissue decurrent through one leaf-gap was never found to be continuous with that decurrent through the gap below. Just before it disappears the enclosed strand sometimes breaks up into two or three small branches.

The line of delimitation between the internal phloem and the xylem is not quite an even one, because small teeth of phloem project irregularly here and there between the peripheral elements of the xylem. The sieve-tubes of the internal phloem are unusually small and angular, and are scattered throughout the whole of its mass. They occur in greatest abundance towards the dorsal side, but no definite protophloem is to be distinguished.

The stem branches frequently in a dichotomous manner. As the stele of the main axis approaches the point of branching

1 On a new type of Fern stele and its probable phylogenetic relations. Annals of Botany, vol. xvi, no. lxi, p. I57, 1902 . 
it flattens out dorsiventrally and finally divides into two by constricting in the middle. The constriction usually takes place in such a manner that there is no communication between the tissues within the xylem-ring and those without it. Sometimes, however, a leaf-trace is given off at the same time as the stem-branches, and then the leaf-gap occurs just between the two branch steles and the ground-tissue is decurrent through it in the ordinary manner. The sclerenchymatous ground-tissue enclosed within the stele is always in direct continuity with that decurrent through the leaf-gaps, except a few very small strands which occasionally occur in the neighbourhood of the branchings. These strands are completely surrounded by their own endodermis and appear to be quite isolated. The leaf-trace departs as a single strongly curved strand, and the curvature increases as it passes out, until sometimes the margins of the gutter meet adaxially and fuse up so as to enclose a small mass of ground-tissue (Fig. 21). This completely closed ring is only to be found over a very short distance; it may never even be formed at all. In either case the leaf-trace eventually divides into two separate halves.

\section{DAVALLIA REPENS.}

The peculiar nature of the vascular system of Davallia repens was first observed by Trécul $^{1}$ in 1885 , but in his account the most interesting feature of its structure was unfortunately overlooked. However, the same type of stele has recently been discovered in certain Lindsayas by Tansley and Lulham (1.c.), who have given it a perfectly correct interpretation. Davallia repens is referred to here because it is necessary to complete the series begun by $D$. aculeata and $D$. pinnata; for the structure of its stele throughout the whole stem is similar to that found in $D$. pinnata at the base of the internodes only. In fact there is no ground-tissue to be found

1 Observations sur la structure du système vasculaire dans le genre Davallia, et en particulier dans le Davallia repens. Comptes rendus, tom. ci, p. I453, 1885 . 
within the stele of $D$. repens at any point whatever. The xylem-ring is about ten times broader in the ventral region of the stele than it is in the dorsal, and the mass of enclosed phloem occupies in consequence a very excentric position (Fig. 23). The dorsal portion of the xylem-ring is very thin and forms a kind of bridge resting on the ventral mass, and arching over the enclosed phloem. The xylem-strand of the leaf-trace departs from this bridge, giving rise to a small gap, through which the internal phloem comes into contact with the external. The endodermis and pericycle which surround the external surface of the stele are not in the least decurrent through the leaf-gap; they pass evenly across it, or at most only dip very slightly inwards. The leaf-gap closes up before even the xylem of the leaf-trace has yet separated off from that of the stem-stele. The structure of the internal phloem is quite normal, and the whole of it is probably to be regarded as metaphloem. The sieve-tubes nearest the bridge are somewhat smaller than the rest, but no definite protophloem can be distinguished, nor does the external protophloem dip in through the gap in the xylem of the bridge. The leaf-trace departs as a single strand, more or less cordate or reniform in section.

The steles of Davallia temuifolia, Parkeri, hymenophylloides and clavata were found to be precisely similar to that of $D$. repens, apart from slight differences in the relative thickness of the ventral mass of xylem and the dorsal bridge, and in the amount of internal phloem present. The same type of stele is also to be found in fifteen or more different species of Lindsaya, but since a paper upon the anatomy of this genus is in preparation by Tansley no further reference need be made to them here. This type of vascular system has been called the Lindsaya-type by Tansley and Lulham, and since it is so characteristic of that genus it will be referred to in this paper by the same name. It should be noted, however, that there are at least two solenostelic species of Lindsaya. One of these, Lindsaya retusa, is perfectly typical and has already been mentioned. The solenostele of the other, 
Lindsaya cultrata, is very small and thin, and, moreover, the leaf-trace departs as two separate strands and not as a single piece.

Tansley has suggested that the two types of stele exhibited by Davallia repens and $D$. pinnata represent structures intermediate between protostely and dictyostely. I thoroughly agree with this, and consider that the type of stele found in $D$. aculeata may now be added to this series. The almost exactly parallel stages passed through by the vascular system in the young plant, even in such an advanced dictyostelic Fern as that described on p. 710 , appear to me to give the suggestion a high degree of probability. As I understand the facts, the idea is that as the leaf and the leaf-trace increased in importance relative to the stem, the phloem lying on the adaxial side of the leaf-trace became extended downwards into the substance of the xylem of the protostele. Gradually reaching further down through the internode this internally decurrent phloem at length came into contact with that decurrent from the leaf-trace below, and a continuous solid core of phloem was thus formed within the stele. Then the ground-tissue lying in the adaxial concavity of the leaftrace also began to extend downwards into the stele, forming at first a prolongation that ended blindly in the core of phloem, but eventually it reached down from one leaf-trace until it met with that decurrent from the leaf-trace below. In this manner an internal strand of ground-tissue was formed which is continuous throughout the stem, and the stele has become a solenostele. Now if such a series of changes were to take place in a dorsiventral rhizome with the leaves inserted only on the dorsal surface, it is extremely probable that the phloem and ground-tissue decurrent from the leaf-traces would not at first occupy the very centre of the stele, but would lie nearest to the dorsal surface on which the leaves are inserted, and hence the ventral portion of the xylem-ring would be broader than the dorsal, as is actually the case in Davallia repens, $D$. pinnata, and $D$. aculeata. What is not so easy to understand is why the xylem-ring should 
ever become of even thickness all round in such a dorsiventral rhizome.

Judging from the Davallias and Lindsayas alone, it would seem that a continuous core of phloem was already present in the stele before the ground-tissue began to be decurrent at all. On the other hand, from Boodle's ${ }^{1}$ description of the structure of the node in certain Gleichenias ( $G$. dichotoma, G. flabellata), it appears that both the ground-tissue and the phloem are decurrent together and for a short distance only into the substance of the xylem. If this may be regarded as the first step in another series of modifications similar to those described above, it follows that in this case a solenostele could be reached without passing through a stage with a solid core of phloem, because both ground-tissue and phloem would be decurrent contemporaneously.

The whole theory is, of course, open to the inevitable criticism that the series of forms in question is perhaps one of reduction, and not one of advance. It seems to me, however, that the increased thickness of the lower region of the xylemring forms an insuperable objection to the general application of any reduction hypothesis to this series. That the vascular system actually has undergone reduction in a number of different Ferns is well known, but although it must be admitted that in some cases structures have resulted which bear a strong superficial resemblance to those described above, it may nevertheless be shown that there are crucially important differences between them. For instance, in Vittaria stipitata, which possesses a dorsiventral rhizome and leaves in two rows on its dorsal surface, the stele is very small and the xylem-ring is only one or two elements thick. Each leaf is supplied with two separate traces, one of which departs from each side of the leaf-gap, and the ground-tissue is decurrent through the leaf-gaps into the stele. So far as the stele itself is concerned each leaf-gap is closed up again before the next above is formed, but the gaps in the xylem-ring remain open long enough to overlap, so that in this respect the stele resembles

${ }^{1}$ On the anatomy of the Gleicheniaceae, 1. c., p. 720. 
that of Cheilanthes lendigera (cf. p. 696). At the level of the leaf-gap the internal ground-tissue is fairly voluminous, but it rapidly decreases as it passes down the internode until only a small strand is left lying close to the dorsal side of the stele. In my specimens this also eventually disappears, so that the decurrent ground-tissue is not continuous from one leaf-gap to another. The stele, therefore, in its general appearance resembles that of Davallia pinnata, but on closer comparison some very important differences come to light. In the first place the xylem-ring of Vittaria stipitata is equally narrow on all sides of the stele, and secondly, as the internal ground-tissue disappears it is not replaced by phloem but by pericycle. Only a slight amount of internal phloem is present at the most; it is even completely wanting on the ventral side of the stele, being replaced by parenchyma.

A number of plants identified as Vittaria elongata were also investigated, and in some of them the stele possessed exactly the same structure as in $V$. stipitata. In others the ground-tissue did not pass in through the leaf-gaps at all, so that, apart from the thin internal sheath of phloem, the whole of the centre of the stele was occupied by pericyclic parenchyma, even at the level of the leaf-gap itself. In several other specimens, again, the vascular system proved to be distinctly dictyostelic and of the simple dorsiventral type described on p. 695. According to Poirault ${ }^{1}$ no internal phloem whatever is to be found in this species; and Jeffrey ${ }^{2}$ states that both the internal phloem and the internal endodermis are wanting, but a certain amount of internal phloem was present in all the specimens that I examined, although it is replaced by parenchyma on the ventral side. It is rather surprising to find so wide a variation in the vascular anatomy of one and the same species, and since it is very difficult to be quite sure about the identification of some of the Vittarias

1 Recherches anatomiques sur les cryptogames vasculaires, Ann. des Sc. Nat., $7^{\ominus}$ sér., t. xviii, p. I 79, I895.

2 The structure and development of the stem in the Pteridophyta and Gymnosperms, Phil. Trans. Roy. Soc. Lond., Series B, vol. cxlv, p. I 32, I902. 


\section{Groynne-Vaughan.-Observations on the}

it is quite possible that some of the specimens examined were wrongly named.

In Antrophyum plantagineum, another dorsiventral Fern with a reduced stele, the ground-tissue is not decurrent through the leaf-gaps into the stele at all. The centre of the stele is occupied by a mass of pericyclic parenchyma as in certain specimens of Vittaria elongata. The internal phloem is very scanty, and as stated by Jeffrey (loc. cit., p. I32) it is altogether absent on the ventral side of the stele. I can also confirm this author upon the absence of the internal phloem over the same region in Antrophyum reticulatum, but while he says that the internal endodermis is also absent, my specimens are distinctly and definitely dictyostelic; the plant has already been mentioned as such on p. 695 .

If these cases be taken as illustrating the effect of reduction upon the different tissues of the stele in a dorsiventral rhizome, it is seen that, in spite of the dorsiventrality, the xylem is equally affected on all sides of the stele. The phloem, on the other hand, experiences greater reduction on the ventral side of the stele than on the dorsal. The pericycle does not appear to be reduced at all, being, in fact, relatively more highly developed than in an unreduced stele. It will now be remembered that none of these indications of reduction are to be found in the stele of Davallia pinnata, or in the Lindsayatype of stele.

The effects of reduction upon the stele of an erect stem with the leaves inserted in several rows all round it are essentially the same as those described above, allowance being made for the difference in habit. A good example of such a structure is provided by Adiantum Aethiopicum. The leaftraces depart as small, very slightly curved arcs, leaving very small leaf-gaps which, so far as the stele itself is concerned, close up at once. The leaf-gaps in the xylem-ring, however, persist long enough to overlap, so that in a transverse section two or three separate strands of xylem may be found enclosed within the stele. The endodermis and ground-tissue as a rule do not dip in through the leaf-gaps at all, and even if they are 
slightly decurrent they disappear almost immediately below. The centre of the stele is occupied almost entirely by a large mass of pericyclic-tissue, the internal phloem being very much reduced, although it is still continuous all round.

According to Jeffrey (loc. cit., p. I32) a reduced stele, which he describes as a tubular central cylinder with a parenchymatous pith, but with no internal phloem or endodermis, is also to be found in Davallia stricta. The authority for the name of the plant on which he made his observations is not given, and I am in doubt as to which species he refers to. In Davallia tenuifolia, var. stricta (Hort.) the structure is exactly the same as in Davallia tenuifolia itself.

\section{The Vascular System of the Petiole.}

The Lindsaya-type of stele is found to be regularly associated with a single very simple vascular strand in the petiole. Seen in section this strand is subrotund or cordate in outline, and contains a xylem-strand shaped like a $\wedge$ with the base directed towards the axis of the stem (Fig. 24). The protoxylem groups are distinct and endarch; one occurs at the end of each arm of the $\Lambda$, and sometimes a third is also present at its apex. The arms of the xylem-strand are sometimes prolonged past the two lateral protoxylems, curving inwards towards the plane of symmetry of the petiole so as to form two small hooks (Fig. 25). These hooks are included in the phloem of the bundle, which is perfectly continuous all round the xylem-strand. According to Bertrand and Cornaille (loc. cit., p. 99) these hooks are always to be considered as present in theory, although they are often so reduced as to be practically obsolete. Using the terminology introduced by these authors in their recent elaborate and exhaustive researches upon the leaf-traces of the Ferns, the trace with two protoxylems would be expressed as a binary chain of divergents, and that with three protoxylems as a ternary chain : the latter resulting from the fusion of two binary chains and the reduction of the median bipolar thus formed to zero. Both cases are considered by Bertrand and Cornaille to be derived 
by reduction from a more complicated type. Vascular strands of exactly the same structure are also to be found in the upper regions of many different petioles, which lower down possess a more complicated vascular system, e. g. Loxsoma Cunninghamii ${ }^{1}$, Dicksonia apiifolia, Davallia ciliata and $D$. hirsuta. According to Bertrand and Cornaille these also may be regarded as reduced structures.

It may be objected, however, that there is hardly any evidence that can be brought forward in support of a theory of reduction in any of these cases. There certainly does not seem to be any general reason why the vascular system at the top of the petiole should ever have been at any time in a more advanced condition than it is at present. It is clear that in any leaf the whole brunt of an increase in the leafsurface must be felt in its entirety by the vascular system of the lower part of the petiole, and especially at or near its extreme base, where the water-current running directly upwards in the stem has to be diverted into the leaf. For this reason any advance towards greater efficiency in the water-conducting apparatus would probably make its first appearance in this region, and I have found, in many cases, that this actually does occur. On the other hand, the waterconducting apparatus that formerly supplied the whole leaf would still suffice for the amount of leaf-surface lying beyond it, provided that it was situated at a point sufficiently high up in the rachis. Apart from the disturbance due to the branching, the vascular system would therefore experience less incentive to modify its form as you pass upwards towards the apex of the leaf, and on this account it would seem preferable to regard the simplicity of its structure in this region as due to the retention of primitive features rather than to reduction. The same simple type of petiolar bundle is, moreover, characteristic of the earlier leaves of the young plants of Dicksonia apiifolia, D. antartica, and even of Cyathea excelsa, in which, especially in the latter, the mature petioles possess a very elaborate vascular system.

${ }^{1}$ Gwynne-Vaughan, 1. c., p. 89, and Fig. 8. 
Upon the whole, therefore, I am inclined to regard this type of leaf-trace as relatively primitive, and as one from which the various more complex forms found in the Cyatheaceae and Polypodiaceae may be derived. Further, I agree with Bertrand and Cornaille in their important conclusion that, except in Acrosticum tenuifolium and A. sorbifolium (in which the petiole seems to possess accessory peripheral strands not derivable from the ordinary system) ${ }^{1}$, every modification undergone by the vascular system of the petiole in these two orders takes place in pursuance of a single main design. As the petiolar bundle increases in size the curvature of the xylem is followed by the vascular strand as a whole. The strand thereby takes up the form of an arc or an $\cap$ (Fig. 26), and as it increases further in size and curvature it comes to assume different forms of gradually increasing complexity, which when seen in section give rise to various different outlines, suggesting an arch, horse-shoe, amphora, \&c. Later on the single strand may break up into separate portions, but these always remain so related to each other that it is still possible to determine the sectional outline of the strand from which they were derived. It has already been stated that a single cordate petiolar bundle is generally related to stems with the Lindsaya-type of stele. The petioles of solenostelic stems also usually contain a single strand, but of varied and often complicated outline. In stems with advanced dictyostelic structure the petiolar bundle is generally broken up into two or more portions; although when the structure is but little removed from solenostely a single strand is often to be found.

According to Bertrand and Cornaille (loc. cit., cap. iii) there are two main regions to be distinguished in the vascular system of a Fern petiole. In that of Cyathea Brunonis, for instance (Fig. I5), there is a large folded curve extending abaxially from $c$ to $c$, and there are two adaxial arcs, one on either side, extending from $c$ to $b$. In petioles of a simpler structure, such as those of Davallia temuifolia (Fig. 25)

1 1. c., p. I33 (Polybotrya Meyeriana and Lomariopsis fraxinifolia). 


\section{Groynne-Vaughan.-Observations on the}

and Davallia speluncae (Fig. 26), \&c., the abaxial curve forms practically the whole of the strand, the adaxial arcs being reduced to small inflected hooks at the ends of the arms. In view of this suggestion it is interesting to find that whenever a petiole branches a vascular strand is always given off to the branch from the point where the adaxial arc or the xylem hook joins on to the abaxial curve. In many of the cases examined a single strand alone passes into the petiolar branch, but in others a second strand is also present, which invariably departs from the abaxial curve itself at the point where it is folded inwards ( $x$ in Fig. I5).

\section{LATERAL SHOOTS.}

In most of the solenostelic and in many dictyostelic Ferns lateral shoots are frequently to be found growing out from the bases of the petioles. Their vascular systems are usually connected up with the adaxial margins of the leaf-trace, rarely, as in Pteris elata and Dicksonia Barometz, with the middle of its abaxial curve. The vascular system at the base of the lateral shoot is often a completely closed cylinder, even when the main axis is perfectly dictyostelic, e.g. Adiantum trapeziforme. Sometimes a single central cylinder with a solid mass of xylem is present. As this stele passes through the cortex of the main axis a core of phloem appears in the centre of the xylem, then a solenostele is formed, and finally it may become more or less dictyostelic, as in Dicksonia Barometz. A similar structure is also to be found in the lateral shoots of Dicksonia adiantoides, but here the change from the solid central cylinder into the solenostele takes place very rapidly, and the solenostele is afterwards permanent. In this plant, and also in Pteris elata, the internal vascular strands do not occur in the lower part of the lateral shoots. In Dicksonia rubiginosa, however, they are usually present, even at the very base. So far as my investigations went on this point they may be summed up generally by stating that the ontogeny of the vascular system of the plant as a whole is very fre- 
quently repeated, although more or less imperfectly, in the development of its lateral shoots.

In Davallia gibberosa two separate vascular strands run out from the stem into each lateral shoot, and the structure at the base of the shoot is similar to that described on page 695 as the simplest form of dorsiventral dictyostely. The lateral shoots are very numerous, but only a few of them ever become properly developed; all the others remain abortive and form no visible projection upon the surface of the stem. These suppressed shoots, however, are still utilized for the purpose of bearing the roots. A number of these arise upon the lower or ventral meristele of the shoot, which now functions merely as a special radiciferous strand.

I am inclined to believe that the radiciferous strands described by Trécul $^{1}$ and Lachmann ${ }^{2}$ in Blechmum braziliense, Scolopendrium officinale, D.C., Asplenium Serra, and others, should also be regarded as the vascular vestiges of suppressed lateral shoots. In the first two examples they consist, according to Lachmann, of a single solid vascular strand, but in Asplenium Serra, Trécul describes them as cylindrical vascular tubes. It has just been shown above that there are a number of Ferns the lateral shoots of which, if arrested at the right stage of their development, would present both these kinds of structure.

In all the Polypodiaceae that I examined the xylem-strand of the true root-stele was invariably diarch. Its long axis was generally tangential to a radius of the stem in the transverse plane, but it was so often oblique, or even parallel to it, that this distinction is evidently of no great value. In their course through the cortex of the stem the root-steles sometimes run directly outwards, more often they run obliquely forwards, or they may even take a zigzag course, running first of all towards the apex and then turning abruptly backwards before reaching the surface of the stem, as in Dicksonia

1 Remarques sur la position des trachées dans les Fougères, l. c., p. 228.

${ }^{2}$ Contributions à l'histoire naturelle de la racine des Fougères. Thésis présentée à la faculté des Sciences de Paris, Sér. A, No. I16, p. 102, I889. 


\section{Groynne-Vaughan.-Observations on the}

rubiginosa. I agree with Lachmann (1.c., p. I30) in thinking that the course of the root-stele depends chiefly upon the different tensions set up in the cortex of the stem, incident upon the varying energy of its terminal growth at the time of the development of the root.

The most striking feature relating to the root-stele is that it possesses no cortex of its own during the greater part of its course through the ground-tissue of the stem. The cortex of the stem runs without break or interruption right up to the endodermis of the root. According to Van Tieghem ${ }^{1}$ this is due to the fact that the definitive apical cell of the root arises in the endodermis so very near to the apex that the cortical tissue lying without it has at that point only attained three or four layers in thickness. The apical cell is subsequently kept in this position by divisions in the subjacent pericycle, which keep pace with the expansion of the surrounding cortex and result in the formation of a 'rootpedicel.'

\section{Histology of the Vascular System.}

In the Cyatheaceae and Polypodiaceae the endodermis is always exceptionally well-marked and characteristic. It always stands out with great clearness in sections treated with phloroglucin, because the radial walls of its cells are lignified and stain red. In all cases examined the endodermis and pericycle on both sides of the stele appear to arise from the division of a common cell-layer. The first-formed elements of the xylem in the petiolar bundles are small annular or spiral tracheides, and they are always grouped into welldefined strands situated on the morphologically internal side of the xylem (Figs. 24, 25, 26, prx.). The metaxylem sometimes closes up in front of the protoxylem elements, so that they appear to be immersed in the substance of the xylem; but nevertheless, as regards these two orders, it may be taken as a general statement that the protoxylems in the petiole

1 Van Tieghem et Duliot, Recherches comparatives sur l'origine des membres endogènes, Ann. des Sc. Nat., Sér. 7, t. viii, p. 540, 1888. 
are primarily and essentially endarch. In many Ferns, both solenostelic and dictyostelic, the individual protoxylems of the leaf-trace are continued downwards into the stem, so that the xylem of the stem is also differentiated from a number of definite endarch or mesarch centres, just as that of the petiole, e. g. Dicksonia rubiginosa, D. davallioides (Fig. 27, prx.), D. adiantoides (Fig. I2), Hypolepis repens, Davallia NovaeZelandiae, Pteris incisa, Dicksonia culcita, Asplenium scandens, \&c. On the other hand, there are a large number of Ferns in which the protoxylems of the petiolar bundles gradually die out towards the base of the leaf-trace, disappearing entirely before, or immediately after, its insertion upon the stele of the stem. No definitely localized protoxylem strands are to be found in the stems of these Ferns, nor are there any spiral or annular tracheides present. The first-formed elements of the xylem either form a fairly continuous layer all round the external periphery, so that the differentiation is more or less centripetal ; or else they appear without order here and there throughout the whole xylem mass, so that the differentiation is quite irregular. In the former case, the small peripheral tracheides may be regarded as forming an exarch protoxylem, although they are all scalariform and differ from those of the metaxylem only in their smaller size and earlier development. In the latter case, there is no difference whatever between the first-formed elements of the xylem and those formed later on, so that a protoxylem as distinct from the metaxylem can hardly be said to exist. A continuous exarch protoxylem was found in several solenostelic Ferns, Loxsoma Cunninghamii ${ }^{1}$, Dicksonia apiifolia (Fig. 28), Davallia platyphylla, $D$. speluncae, $D$. hirta, D. marginalis, \&c. In some dictyostelic Ferns also the peripheral elements are smaller, and upon the whole develop earlier than the rest, but the subsequent differentiation is usually rather irregular, as in Gymnogramme japonica, G. vestita, Adiantum trapeziforme, Dicksonia Barometz, \&c. In the Lindsaya-type of stele the large ventral mass of xylem seems always differentiated more or less

1 Gwynne-Vaughan, 1. c., p. 79, Fig. 3. 
irregularly (Fig. 23). In Cyathea Brunonis, Alsophila excelsa, Dicksonia culcita, and in several other dictyostelic Ferns with large meristeles, the leaf-trace protoxylems are decurrent along the margins of the leaf-gaps and even for some distance below the gap itself, but the differentiation of the main mass of xylem is irregular, or sometimes more or less centripetal.

These observations are of course not exhaustive, but, so far as they go, it appears that whenever definite protoxylem strands consisting of spiral and annular elements do occur in the stem they are in relation, directly or indirectly, to the decurrent protoxylems of the leaf-trace. On the other hand, the small scalariform tracheides, which are the first to be formed at the periphery of the xylem of the stem, may in many cases be regarded as constituting a definite exarch protoxylem proper to the stem itself.

The phloem is generally separated from the xylem by a continuous layer of parenchyma (the 'vasal-parenchym' of Strasburger), although sieve-tubes are occasionally to be found in direct contact with the tracheides. The parenchymatous cells of the phloem generally contain less starch and more proteid matter than those of the xylem or those of the abovementioned 'xylem-sheath.' This distinction, however, is very variable, and seems to depend upon such factors as the season, the condition of growth, \&c. In the case of the Ferns, therefore, it seems advisable to give no greater importance to the terms phloem-parenchyma, xylem-parenchyma, and xylemsheath than as indicating certain definite topographical regions in a common vascular ground-tissue. Cavity-parenchyma is very generally present in the petioles of the Cyatheaceae and Polypodiaceae, occurring at points just in front of the protoxylem strands (Figs. 24, 25, 26). It consists of rather large cells, the longitudinal walls of which are transversely plicate on the side facing the xylem. These cells have living contents and thin cellulose walls, except in Loxsoma Cunninghamii ${ }^{1}$, where they become reticulately thickened and lignified. In Dicksonia apiifolia, Davallia hirta, and D. Novae-Zelandiae, 
it is clearly shown that the formation of cavity-parenchyma is really due to a kind of thylosis. At a certain stage in the development of the young petiole the cells of the xylem-sheath bordering upon the protoxylem strands increase rapidly in size, and send protrusions in between the rings and spirals of the first-formed elements, so as partly to fill up their cavities (Fig. 29). The protoxylem elements at maturity are almost completely disintegrated, and these protrusions give rise to the irregularly folded appearance of the longitudinal walls. Sometimes, when the leaf-trace protoxylems are decurrent down the steles of the stem their cavity-parenchyma also accompanies them, as in Dicksonia davallioides (Fig. 27), Davallia Novae-Zelandiae, Hypolepis repens, \&c.

A number of irregularly shaped siliceous nodules are to be found in the cells of the xylem-parenchyma of Davallia repens, $D$. tenuifolia, D. hymenophylloides, and in most of the Lindsayas with the same type of stele. They have exactly the same form and appearance as those described by Boodle ${ }^{1}$ in Lygodium dichotomum. In Davallia repens and Lindsaya lobata they also occur in the phloem-parenchyma.

The first-formed elements of the external phloem are always more or less distinct from the rest, and constitute a fairly definite protophloem. In most cases a definite protophloem is also to be found on that side of the internal phloem furthest away from the xylem, but in the Lindsayatype of stele (Figs. 22 and 23) and also in several solenosteles, Davallia platyphylla, D. strigosa, D. hirta, Lindsaya retusa, \&c., no internal protophloem can be made out at all. It has already been mentioned that internal phloem is altogether absent from the ventral side of the stele in Vittaria stipitata, Antrophyum plantagineum, $A$. recticulatum and $A$. semicostatum.

The petiolar bundle of the Cyatheaceae and Polypodiaceae is essentially concentric throughout. The phloem is most plentiful on the abaxial side of the xylem, but at the same

${ }^{1}$ On the anatomy of the Schizaeaceae, Annals of Botany, vol. xiv, no. 1viii, pp. 364 and 402,1901 . 
time it is never altogether absent from the adaxial side (Figs. 24, 25, 26). The protophloem is always quite distinct on the abaxial side, and it is nearly always to be found on the adaxial side as well. Indeed when the petiole contains a single strand only, the protophloem can often be followed all round its adaxial concavity. Whenever the xylem strand of the petiole is prolonged into a hook, the protophloem, if present, always passes straight across over the bay that lies between the hook and the main strand (Fig. 26). It appears, therefore, that the sieve-tubes situated within the bay itself must be regarded as belonging to the metaphloem. In most cases the sieve-tubes within the bay of the hook are quite normal (Figs. 25, 26), but in a good many Ferns they exhibit a special kind of structure. Their walls are unusually thick, and when unstained have a swollen pearly appearance. The additional thickening is all cellulose, and consists of two fairly distinct layers, the innermost of which is broader, softer, and less refractive than that next the middle lamella. They have rather more contents than the ordinary sieve-tubes, and the deeply staining granules characteristic of typical Fern sievetubes are rarely if ever to be found in them. For all that they do not seem to be essentially different from typical sieve-tubes, although it is doubtful whether they continue to function as such. One form of sieve-tube graduates insensibly into the other; indeed, towards the base of the petiole the thick-walled sieve-tubes are nearly always replaced by the typical form. The thickened sieve-tubes may also occur all round the adaxial side of the leaf-trace ; especially near the protoxylems, and again on the abaxial side of the strand on the flanks of the xylem. They are especially well shown in the petioles of Dicksonia adiantoides, D. culcita, D. punctiloba, Davallia aculeata, $D$. platyphylla, and $D$. davallioides. These modified sieve-tubes occupy exactly the same position as the lignified 'phloem-fibres' in the leaf-traces of Loxsoma Cunninghamii ${ }^{1}$ and of certain species of Aneimia ${ }^{2}$, and

1 Gwynne-Vaughan, 1. c., p. 83, Figs. 5 and 6.

2 Eoodle, On the anatomy of the Schizaeaceae, 1. c., p. 400. 
I have no doubt that these also represent metamorphozed sieve-tubes.

Attention must finally be drawn to the very remarkable mucilage ducts or vessels that are to be found in the external phloem of the petiolar strands of Dicksonia Barometz. They occur in the metaphloem, and are easily distinguished from the rest of its elements by their greater size and their dense, deeply staining mucilaginous contents. The structure of these elements was not investigated in detail, but it appears that they are formed by a number of elongated cells arranged in vertical series, the walls of which have become reabsorbed at certain points where they are contiguous, so that their contents are continuous throughout the series. In position they correspond to the inmost sieve-tubes of the metaphloem, but the perforations appear to be true perforations, and they are much too wide to resemble the sieve-plates. Whether they are to be regarded as metamorphozed sieve-tubes or not was not decided. From a figure given by Bertrand and Cornaille (loc. cit., p. $5^{8}$, Fig. 30 ) similar structures appear to be present in the petiole of Dicksonia regalis.

\section{The Systematic Value of the Vascular Anatomy.}

No really satisfactory conclusion upon the degree of importance that ought to be assigned to the vascular anatomy as a factor in the classification of the Polypodiaceae can be arrived at until the structure of at least a majority of the species of the various genera has been correctly described. The facts already at our disposal, although not so extensive as one might wish, are still sufficient to show that the characters brought to light by the study of the vascular anatomy will probably prove to be of great assistance in constructing a natural classification, and they must certainly be taken into account by the systematists. The anatomy of so many species, even in the genera especially dealt with in this paper, is still unknown, that the tentative nature of any conclusions drawn from the results obtained must, in the first place, be thoroughly understood. 
If the solenostele and the Lindsaya-type of stele are to be regarded as the most primitive types of vascular arrangement in the Polypodiaceae, as suggested above (p. 7 7 ), it must at the same time be admitted that these primitive characters do not run parallel with Professor Bower's division of the order into Gradatae and Mixtae. Bower himself, however, supports the view that several different lines of descent may be represented within the Polypodiaceae alone ${ }^{1}$, and it is very probable that a more or less similar primitive type of vascular arrangement might occur in the primitive members of each line of descent. It follows that those genera in which the solenostele, or the Lindsaya-type of stele, is predominant may be regarded as relatively primitive, at any rate within their own particular family. The prevalence of the primitive types of stele in the various genera and subgenera may be summed up as follows.

All the species of Dennstaedtia (regarded by Hooker in the 'Synopsis Filicum' as a section of Dicksonia) that have hitherto been examined prove to be essentially solenostelic. It must be noted, however, that in D. rubiginosa the solenostele is not quite typical, and that additional internal vascular strands are also present.

Microlepia, including Saccoloma, is placed in the 'Synopsis Filicum' among the Davallias, and, apart from the fact that additional internal vascular strands are present in the Saccolomas (cf. p. 703), all the species that have been examined are typically solenostelic with two exceptions only. Of the exceptions, Davallia ciliata is dorsiventrally dictyostelic, and is clearly out of place among the Microlepias ${ }^{2}$. It is placed by

${ }^{1}$ Bower, Studies in the morphology of spore-producing members, no. 4 , Phil. Trans. Roy. Soc. London, Series B, vol. cxcii, p. I23, I899.

${ }^{2}$ Professor Bower has been kind enough to examine the sorus of this species for me, and he finds that 'the receptacle is almost flat, and the sporangia of various ages are intermixed; successive ones being interpolated without order between those already there. The older sporangia are long stalked, so as to raise their heads above the younger. There appears to be no regularity of orientation. The annulus is vertical. All these characters stamp it as one of the Mixtae, and it should find its place elsewhere than among the Microlepias.' 
J. Smith ${ }^{1}$ in the section Leucostegia under the synonym of $L$. hirsuta, and this arrangement is quite in accordance with its vascular structure. The other exception is Davallia pinnata, the stele of which exhibits a structure intermediate between a solenostele and the Lindsaya-type of stele. This plant has been removed from Microlepia by $\mathrm{H}$. Christ ${ }^{2}$ and given a section to itself: Wibelia. The anatomy agrees with this separation, and indicates a closer relationship to the Lindsayas than to Microlepia. Davallia Novae-Zelandiae (Leptolepia, Met.) is regarded by J. Smith and H. Christ as a species of Microlepia, but in the 'Synopsis Filicum' it is included in the section Leucostegia. Since, however, it proves to be typically solenostelic, and the section Leucostegia itself is a predominantly dictyostelic one, the anatomy gives unqualified support to the two former authorities.

Probably all the species of the genus Hypolepis are solenostelic, although the four species mentioned in this paper are the only ones in which the anatomy has been sufficiently described.

Prantl ${ }^{3}$, in 1892 , proposed to divide the Polypodiaceae into four great tribes : the Aspidieae, the Asplenieae, the Pterideae, and the Polypodieae. At the same time he founded the subtribe Dennstaedtiinae to include the genera Dennstaedtia, Microlepia, Leptolepia, Saccoloma and Hypolepis, which he regards as containing all the most primitive species of his first tribe, the Aspidieae. It has been shown above that essentially the same type of primitive vascular system is to be found in every species of this sub-tribe in which the anatomy is known. Therefore, as regards the primitive nature of the sub-tribe as a whole, Prantl receives strong support from the anatomy, but to decide whether all these genera belong to the base of one and the same line of descent, or not, is another and a very difficult question; as he himself acknowledges. Dennstaedtia and Microlepia certainly appear

${ }^{1}$ Historia Filicum, 1875 .

2 Die Farnkräuter der Erde. Jena, I 897.

3 Das System der Farne, Arbeiten aus dem K. Bot. Gart. z. Breslau, Bd. i, Heft i, I892. 


\section{Groyne-Vaughan.-Observations on the}

to go together, and they both come under Bower's division of Gradatae. It seems probable also that the genus Loxsoma should be regarded as more nearly allied to these two genera than to any others. The development of the sorus in Leptolepia and Saccoloma is not known, but Hypolepis belongs to the Mixtae. According to the anatomy Leptolepia goes with the Microlepias, but it may prove that a distinction should be made between Saccoloma and Hypolepis and the rest of the group, and also between each other. As a secondary character of the Dennstaedtiinae Prantl states that, except in Saccoloma, hairs are present instead of paleae throughout the group. So far as the species that I examined are concerned this certainly holds true.

The Lindsaya-type of primitive stele has been found in all the species of that order hitherto examined, except in L. retusa and L. cultrata, which possess solenosteles. The same type of stele is also characteristic of the sections Odontoloma and Stenoloma, which are placed by Hooker in the genus Davallia. The anatomy, therefore, agrees with $\mathrm{H}$. Christ in removing these two groups from Davallia and placing them among the Lindsayas. J. Smith also places Odontoloma in his tribe Lindsaeeae. The section Stenoloma he removes from the Davallias, but places it in his tribe Saccolomeae under the synonym of Odontosoria. It should be mentioned that Davallia (Stenoloma) aculeata is somewhat exceptional, in that it exhibits a type of solenostely peculiar to itself. H. Christ has given it a section of its own: Lindsayopsis. It has already been stated that according to the anatomy Davallia (Microlepia) pinnata should be included with the Lindsayas rather than with the Microlepias. The most primitive genera in Prantl's second tribe, the Asplenieae, were considered by him to be Lindsaya, Lindsayopsis, Wibelia (Davallia pinnata), Odontosoria (Stenoloma) and Davallia. If the last genus, Davallia, be excluded he finds here again support from the anatomy, since all the species in the four remaining genera possess a primitive vascular system, and, with three exceptions only, they all possess the same type of stele. Finally they all 
belong to Bower's division of Mixtae. The presence of paleae instead of hairs is given by Prantl as a secondary characteristic of this group, and it held good in all the examples examined by me.

Of the genus Davallia there now remain to be discussed the sections Humata, Eudavallia, Leucostegia and Loxoscaphe. All the species that were examined in these sections proved to be perfectly dictyostelic, with the single above-mentioned exception of Davallia (Leucostegia) Novae-Zelandiae. The vascular arrangement was dorsiventral in every case, except Davallia Emersoni and $D$. contigua which are radially symmetric. These two species form the sub-section Prosaptia, which, according to J. Smith, should be removed from the Davallias altogether. Upon the whole the anatomy of the above sections would agree better with the Polypodi than with the rest of the genus Davallia.

Only a few species of Pteris are known to be solenostelic. One of these, $P$. incisa, is isolated with its varieties as the section Histiopteris both by Smith and H. Christ. Another, $P$. scaberula, together with $P$. viscosa, the anatomy of which is as yet unknown, form, according to Christ, the separate section Paesia. Famesonia is solenostelic, and so also are two species of Pellaea. All these belong to Prantl's third tribe, the Pterideae, the most primitive genera of which he considers to be Lonchitis, Pteridium, and Paesia. It appears, therefore, that the agreement of the anatomy with his arrangement is not so complete in this as in the two previous tribes.

In his fourth tribe, the Polypodieae, solenosteles are still more rare. It is true that the Polypodiums of the section Dipteris are solenostelic, but Seward and Dale ${ }^{1}$ have shown that it must be removed from the Polypodiums altogether. They even go so far as to give it a family to itself, apart from the Polypodiaceae. The only other case of solenostely that I am aware of in this group is in Polypodium punctatum, and here the vascular system so very closely resembles that of Hypolepis that, since Hooker himself has remarked that this

1 On the structure and affinities of Dipteris, 1. c., p. $5^{\circ 2}$. 


\section{Groynne-Vaughan.-Observations on the}

plant (1. c. p. $3^{\mathrm{I}}$ 2) 'is very closely related to Euhypolepis,' it may confidently be removed to that genus.

Upon the whole, therefore, Prantl receives considerable support from our results, since nearly all of the genera regarded by him as relatively primitive in their respective family branches also prove to be characterized by the possession of a primitive vascular structure, especially as regards his first two tribes. Nevertheless, this must not be taken to mean that each, or even any, of his tribes actually represent separate single lines of descent. Much further research is necessary on all sides before this question can be satisfactorily faced, and the above discussion merely serves to point out the fact that anatomical considerations must play an important part in coming to any conclusion.

\section{Conclusion.}

The stelar theory has undergone many modifications under the hands of different authors since it was first introduced by Van Tieghem, and the exact meaning of the word 'stele' as now used is getting somewhat obscure. It is, however, becoming more and more apparent that the chief value of the conception lies in its ontogenetic and phylogenetic significance, whereby the stele of the stem may be regarded as the central cylinder of the young plant and all those tissues of the mature axis that result from its modification, or, as Farmer and Hill ${ }^{1}$ would prefer to have it, the central cylinder of the young plant and all those vascular tissues of the mature axis that result from its modification. As a consequence of the first point of view it must also be held that there exists a regional distinction of primary importance between the stelar tissue and the cortex. Therefore, when considering a vascular arrangement such as a dictyostele or a solenostele it becomes impossible to neglect the question, whether the central parenchyma is to be regarded as stelar, and therefore morphologi-

\footnotetext{
${ }^{1}$ On the arrangement and structure of the vascular strands in Angiopteris evecta and some other Marattiaceae, Annals of Botany, vol. xvi, no. 62, p. $39^{2}, 189^{2}$.
} 
cally distinct from the cortex; or as cortical, in which case the stele, or the separate portions of it, must possess a definite internal as well as an external limit. Supposing the central parenchyma in question to be really stelar, then it must have come into existence by the substitution in the stele of parenchymatous elements for those that were previously vascular. To take the case of the Cyatheaceae and Polypodiaceae in particular; if the course of development actually did take place in the manner suggested above ( $\mathrm{p} .7 \mathrm{I} 7)$ ), then each cell of the central parenchyma must have belonged in previous generations successively to the xylem, phloem, pericycle and endodermis before attaining its present condition. On the other hand, if the central parenchyma be regarded as cortical, then the stelar elements at certain points in the stele through successive previous generations must have undergone fewer and fewer divisions as they developed, while the divisions in the cortex opposite these points must have correspondingly increased. Therefore the cortical tissue at these points would eventually encroach upon the vascular, and would in time come to occupy the greater part of the centre of the stele.

It has been very generally assumed that if the distinction between stele and cortex is really a morphological one, the two regions must of necessity be marked off from one another by the earliest cell-divisions at the apex, or by the so-called histogenetic layers. But recent researches upon apical meristems ${ }^{1}$ have shown that the earlier tangential divisions in the segments of an apical cell, and even the histogenetic layers of Hanstein, are not only very inconstant and unreliable, but also that they bear no invariably fixed relations to any of the subsequent tissue-differentiations in the mature regions of the plant, and that in consequence they have little or no general value as morphological criteria. It does not appear to me that the regional significance of the stele is in any way bound up with the maintenance of these distinctions. The consideration of the morphology of the stele can only begin when

\footnotetext{
' Schoute, Die Stelärtheorie, Groningen, 1902 : also Tansley, Proceedings of the Linnean Society, Nov. 20, 1902.
} 


\section{Groynne-Vaughan.-Observations on the}

that region is definitely and satisfactorily delimited. It is not directly concerned with any question as to which particular segment it is in which the tangential wall appears that first of all delimits it. All that is required is that a definite delimitation should actually be possible at one point or another during the course of its development in a majority of cases sufficiently great to render the statement general.

According to the view taken by Farmer and Hill the attention is concentrated upon the vascular tissue alone, and therefore the stele as a whole is deprived of any regional distinction. I quite agree with them that it is inconvenient, from a descriptive point of view, to draw theoretical distinctions that have no histological expression between different regions of the general ground-tissue. But at the same time I hold that it would be a great mistake to give up all attempts to discover the phylogenetic history, and the precise method of origin, in each particular case of such tissues as the central parenchyma, and even as the much abused endodermis. Full information upon such points is bound to be of considerable value, and the ability to state of two plants presenting the same type of structure whether they reached this condition by passing through the same, or through different series of changes would throw light upon many interesting problems which might otherwise remain obscure. For instance, in the Cyatheaceae and Polypodiaceae, it has been suggested above that, whether by the intrusion of the cortex, or by the metamorphosis of stelar tissue, the first appearance of the internal parenchyma must have taken place at the periphery of the protostele, and at points just above the departure of the leaf-traces. This displacement, or transformation, of the vascular tissue then advanced gradually inwards from these points until even the most central region of the stele was affected by it. The internal parenchyma, therefore, from the moment of its first appearance, was always in contact with the cortical parenchyma.

Now several other methods of procedure might also have taken place by which a similar result could be attained. For 


\section{Anatomy of Solenostelic Ferns.}

instance, the first appearance of internal parenchyma might take place in the centre of the xylem of the protostele. The xylem-ring thus formed might subsequently become interrupted by the departure of the leaf-traces, and finally a structure resembling a solenostele might be attained by the gradual differentiation of phloem and endodermis through the leaf-gaps and all round the inside of the xylem-ring. Again, an internal endodermis might be differentiated within the internal parenchyma before the xylem-ring is interrupted, in which case the phloem alone would have to extend around the inside in order to bring about the above-mentioned structure. Finally, the internal phloem and endodermis might both be differentiated within the internal parenchyma before ever the xylem-ring is interrupted, and then the formation of leaf-gaps would do no more than set the internal tissues in continuity with the external. Although the first of these methods alone has been ascribed to the Cyatheaceae and Polypodiaceae above, it is very probable that the others may occur in other orders. Indeed Boodle ${ }^{1}$ has already made some suggestions on similar lines in relation to the Schizaeaceae.

In a vascular system arising according to the two last methods it is evident that there can be no two opinions regarding the stelar origin of the central parenchyma. In the first two cases, however, it is possible to conceive of the intrusion of the cortex into the stele in the manner previously explained. It is difficult to see where any conclusive evidence upon this point, one way or another, is to be sought for. It is, however, reasonable to suppose that if the young plant of such a Fern as Davallia pinnata be examined at different stages in its development, some light may be thrown on the matter by the comparison of the state of affairs at those regions of the apex where the distinction between stele and cortex first becomes evident: or, perhaps, even by the comparison of the same region in the mature plant with that in a typically solenostelic Fern.

${ }^{1}$ On the anatomy of the Schizaeaceae, 1.c., p. 407, and Further observations on Schizaea, Annals of Botany, vol. xvii, no. lxvii, p. 530, 1903. 


\section{Groynne-Vaughan.-Observations on the}

The simplest way of getting over the matter would be to accept the stelar origin of the central parenchyma in all cases, and to regard the internal endodermis as never strictly homologous with the outer. But still the other alternative is theoretically possible, and should not at once be rejected as inherently improbable.

In conclusion I have to thank Professor Bower and Dr. Lang for the assistance they have given me in obtaining material, and for their valuable advice upon various points in relation to my work. I have further to express my gratitude to the Director of the Royal Gardens, Kew, the Director of the Royal Gardens, Calcutta, and to Mr. Hemsley of Darjeeling, for their kindness in providing me with much useful and valuable material. 


\title{
EXPLANATION OF FIGURES IN PLATES XXXIII, XXXIV, AND XXXV.
}

\author{
Illustrating Mr. Gwynne-Vaughan's Paper on Solenostelic Ferns.
}

Figs. 1 2, 20, and 22 to 28 are from photographs; a more or less under-exposed print being used as a camera-lucida drawing. All the other figures, except Fig. 29, are diagrams. Fig. 29 was drawn from the section. The following lettering is used throughout; L.T., leaf-trace; $e$, external endodermis; $e^{\prime}$., internal endodermis ; $P$., external pericycle; $P^{\prime}$., internal pericycle ; $p h$., external phloem; $p h^{\prime}$., internal phloem; $p p h$, external protophloem; $p p h^{\prime}$., internal protophloem; prx., protoxylem.

Fig. I. Dicksonia punctiloba. Diagram of vascular system of rhizome including a node and the base of a leaf-trace. The upper surface of the rhizome would face the observer.

Fig. 2. Dicksonia apiifolia. Ditto.

Fig. 3. Davallia Speluncae. Ditto.

Fig. 4. Hypolepis millifolia. Ditto: l.sh., lateral shoot arising from basiscopic margin of leaf-trace ; $a$., vascular strand running from free margin of lateral shoot to proximal margin of leaf-trace; $b$., a similar strand running to distal margin of leaf-trace.

Fig. 5. Hypolepis tenuifolia. Ditto: l.sh. and $a$. as in Fig. 4; c., vascular strand running from free margin of leaf-gap to acroscopic margin of leaf-trace.

Fig. 6. Hypolepis repens. Ditto: l.sh., $a$. and $b$. as in Fig. 4 ; l.sh', lateral shoot arising from acroscopic margin of leaf-trace.

Fig. 7. Nothochlaena Marantae. Diagram of vascular system of rhizome including two nodes and the bases of the departing leaf-traces. The upper surface of the rhizome faces obliquely towards the top of the plate.

Fig. 8. Pellaea rotundifolia. Ditto.

Fig. 9. Gymnogramme calamelanos. Ditto. The stem is radial.

Fig. I0. Plagiogyria biserrata. Diagram of tiansverse section of the vascular system. The steles are unshaded; the dark masses sc.e. and sc.i. represent sclerenchyma respectively external and internal to the stelar ring.

Fig. II. Dicksonia adiantoides. Diagram of vascular system of rhizome, including a node and the base of a leaf-trace : l.sh., lateral shoot arising from basiscopic margin of leaf-trace; $i_{\text {.s. }}$, ridge upon internal surface of solenostele. The upper surface of rhizome would face the observer.

Fig. I2. Dicksonia adiantoides. Transverse section of the free margin of a leafgap in the solenostele: i.s., the free xylem-strand forming a projection on the internal surface.

Fig. 13. Dicksonia rubiginosa. Diagram of the vascular system of the rhizome including a node and the base of a leaf-trace : l.sh. and i.s. as in Fig. II ; l., lacunae in the solenostele not related to the departure of a leaf-trace. The upper surface of the rhizome would face the observer. 


\section{Groynne-Vaughan.-On Solenostelic Ferns.}

Fig. I4. Pteris elata, v. Karsteniana. Ditto. A piece is supposed to be cut out of the side of the solenostele so as to show the internal vascular system. Note that a small strand lying within the second vascular ring is also present. The stem is radial.

Fig. I5. Cyathea Brunonis. Diagram showing the arrangement of the vascular strands in the petiole: $a ., b$. and $c$. indicate those below which the internal vascular strands of the stem are inserted.

Fig. 16. Cyathea Brunonis. Diagram of one side of the acroscopic half of a leaf-gap; seen from within, and showing the insertion of the internal strands of the stem, $a_{.}, b$. and $c$.

Fig. I7. Dicksonia Barometz. Portion of the vascular system of the stem; seen from within, and showing the departure of three leaf-traces.

Fig. 18. Alsophila excelsa. Diagram of vascular system of a young plant in median longitudinal section. The xylem is black, the phloem lightly shaded and the endodermis is indicated by a dotted line. The ground-tissue is left white.

Fig. I9. Davallia aculeata. Diagram of vascular system of rhizome including a node and the base of a leaf-trace : $p h^{\prime}$., internal phloem. The external phloem is not indicated. The upper surface of the rhizome would face the observer.

Fig. 20. Davallia aculeata. Transverse section of the stele of the rhizome in the middle of an internode : $s c l^{\prime}$., sclerenchymatous internal ground-tissue.

Fig. 21. Davallia pinnata. Diagram as in Fig. 19. The vascular system is supposed to be curved so that the two cut ends face the observer more or less obliquely: $p h^{\prime}$. , internal phloem.

Fig. 22. Davallia pinnata. Transverse section of the stele of the rhizome in the upper part of an internode: $s c l$. and $s c l^{\prime}$., sclerenchyma belonging respectively to the external and internal ground-tissue.

Fig. 23. Davallia repens. Transverse section of the stele of the rhizome at a point immediately above the leaf-gap. The petiolar bundle has not yet become free.

Fig. 24. Davallia repens. Transverse section of the vascular bundle of the free petiole.

Fig. 25. Davallia tenuifolia. Ditto: Hk., adaxial hook of the xylem.

Fig. 26. Davallia Speluncae. Ditto: $H k$., as in Fig. 25 ; Cp., cavityparenchyma.

Fig. 27. Dicksonia davallioides. Portion of a transverse section of the solenostele : $C p$., cavity-parenchyma.

Fig. 28. Dicksonia apiiffolia. Portion of a transverse section of the solenostele.

Fig. 29. Dicksonia apiifolia. Cells of the cavity-parenchyma sending protrusions into a disintegrating protoxylem element of a young petiole. 


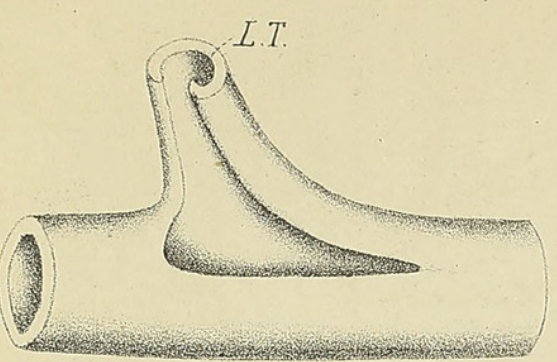

F'ig. 1

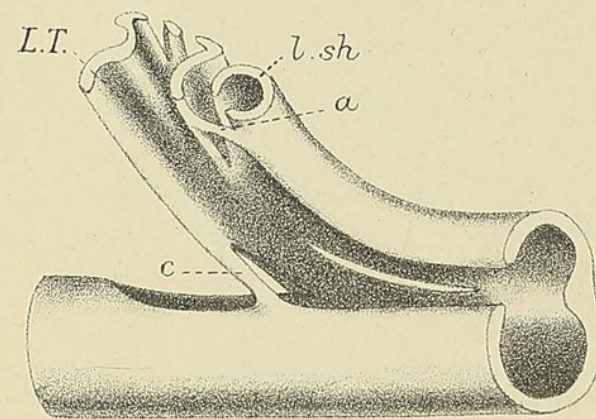

Fig. 5

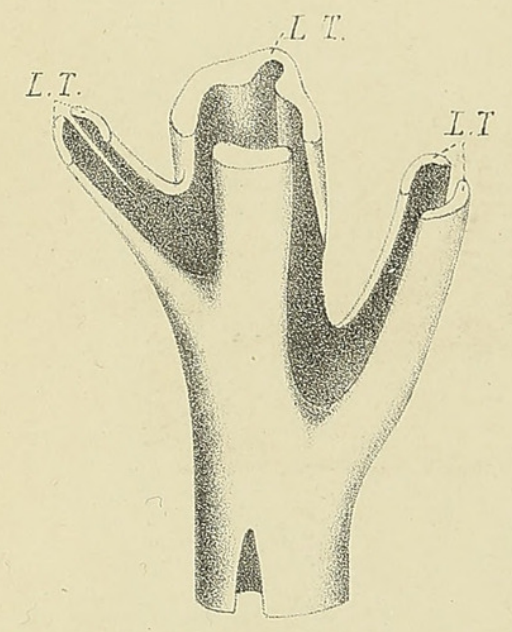

Fig. 9

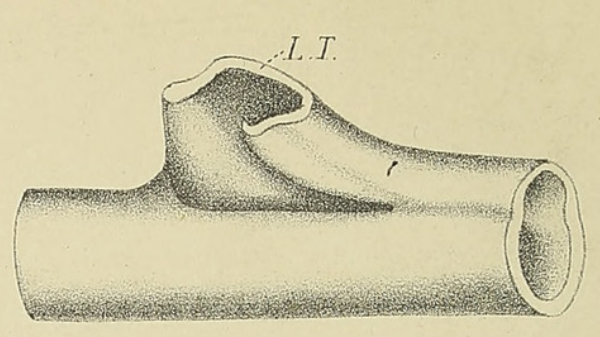

Fig: 2 .

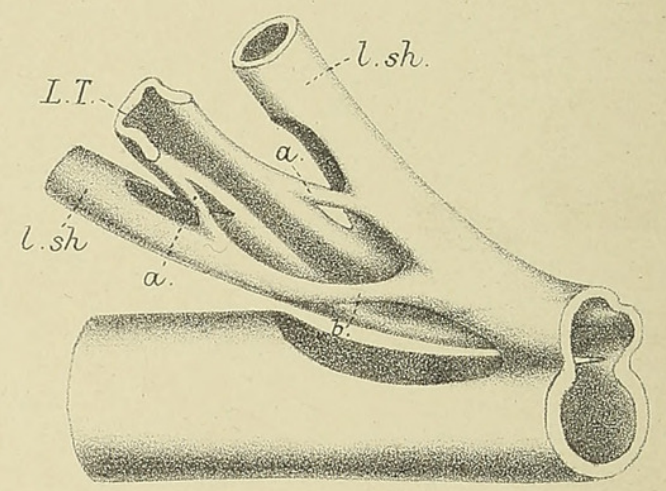

Fig. 6 .

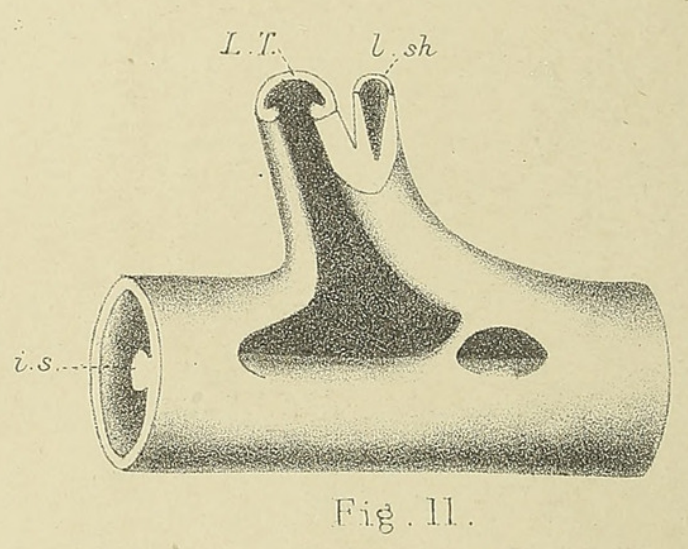

L.T. 2.

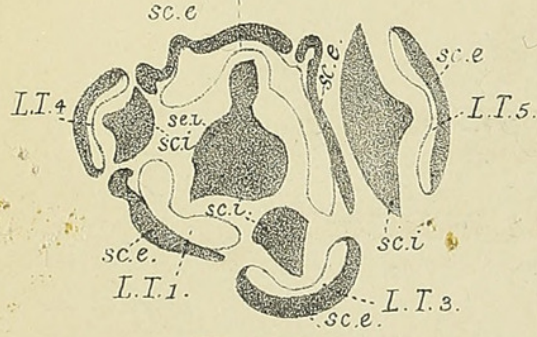

Fig. 10.

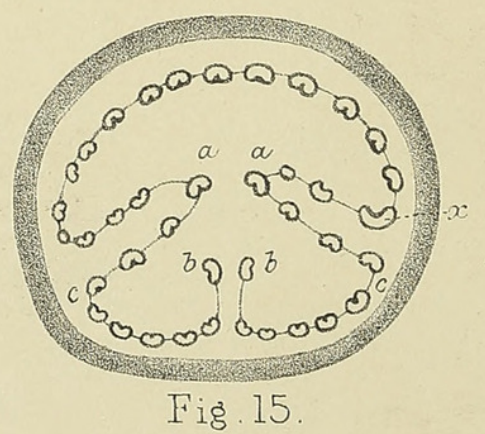

Fig. 15 .

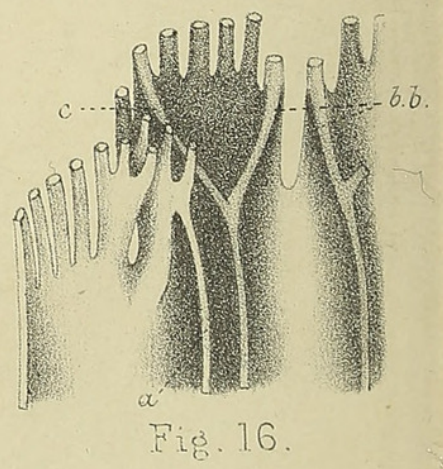

D.T.G.V. ăel. 


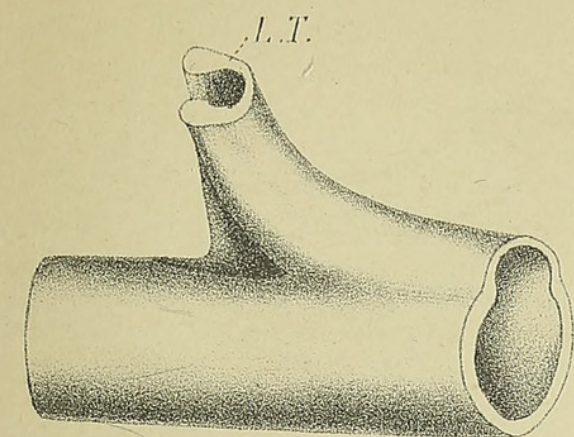

Fig. 3.

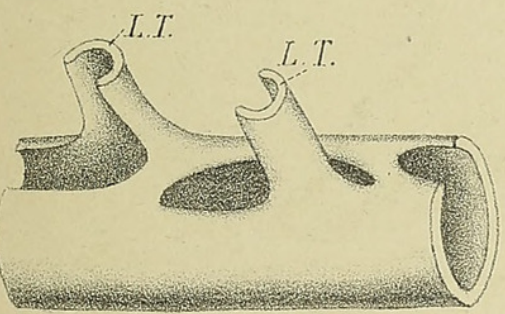

Fig. 7

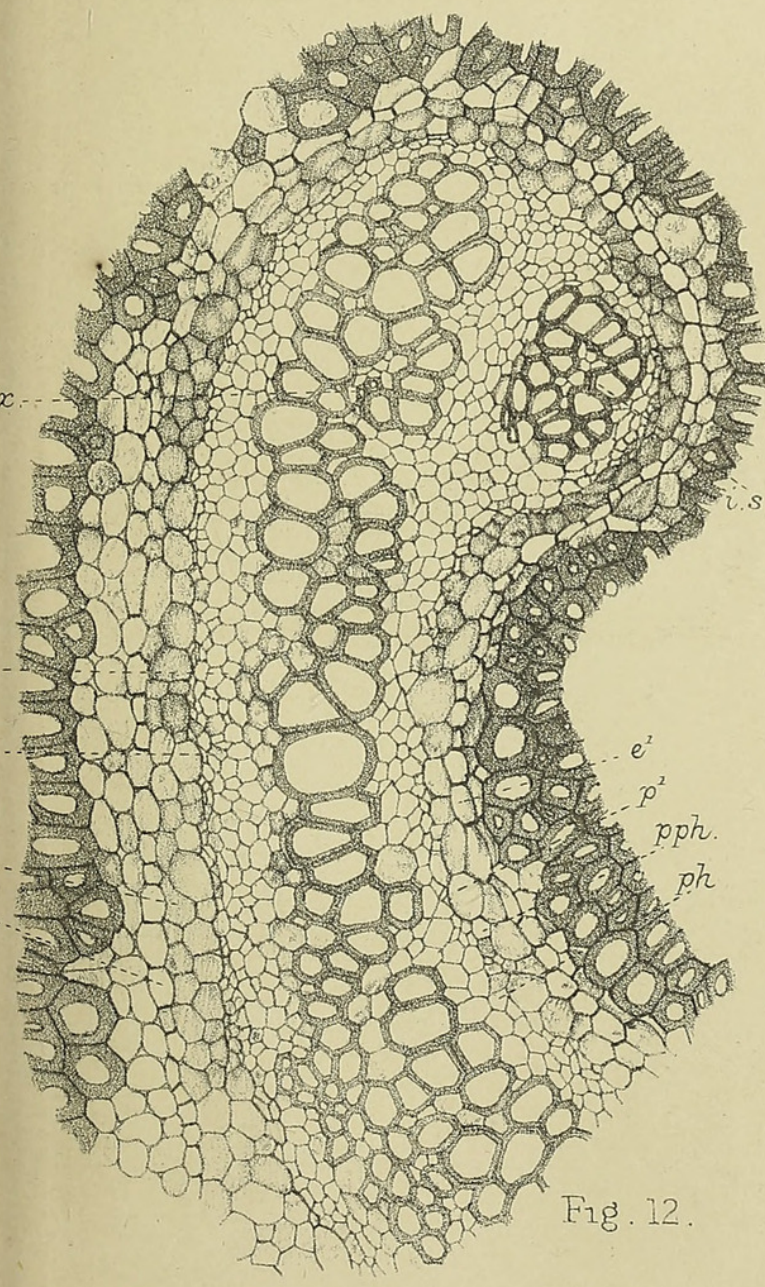

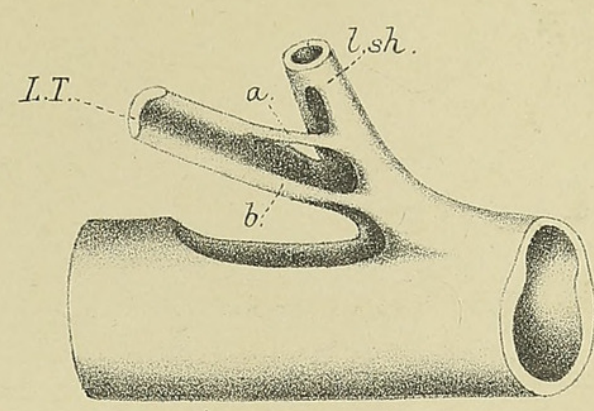
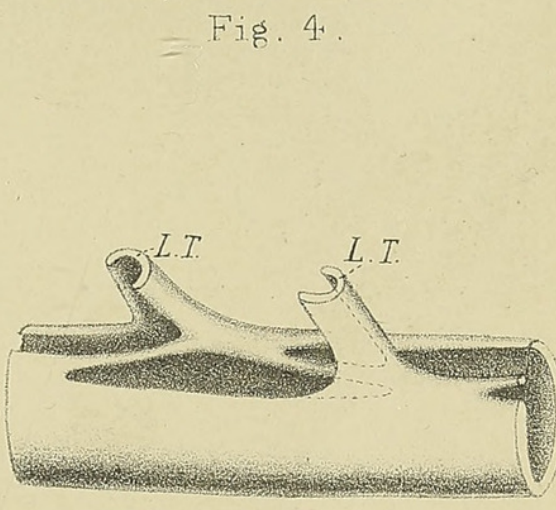

Fis. 8 .
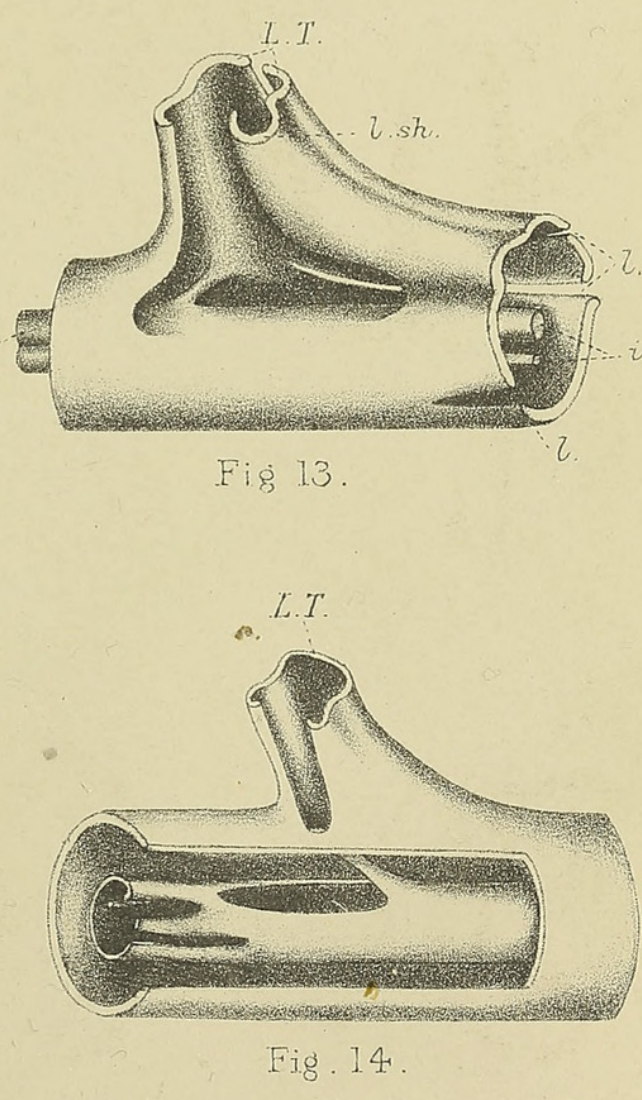

University Press Oxford 


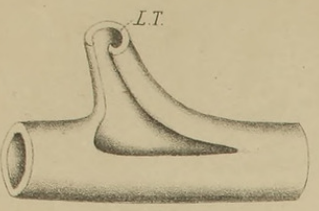

Fig. 1

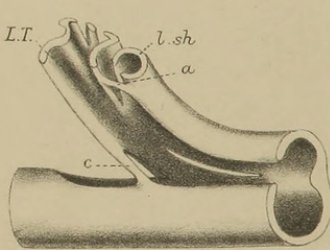

Fig. 5

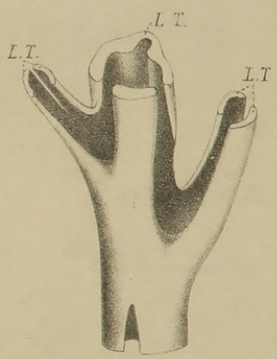

Fig. 9 .

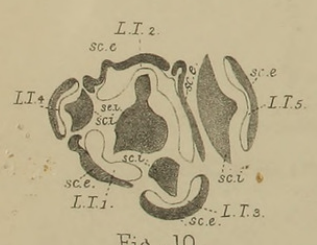

Fig. 10.

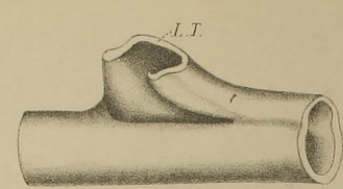

Fig: 2 .

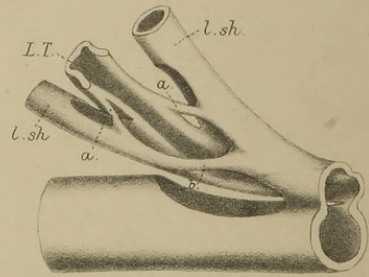

Fig. 6.

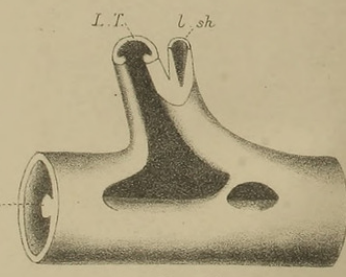

Fig. 11

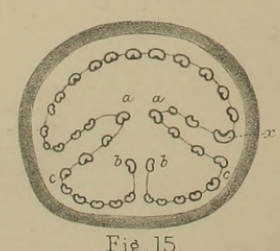

Fig. 15.

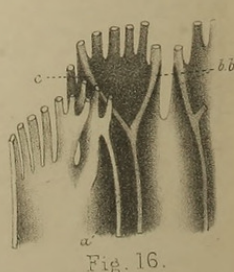

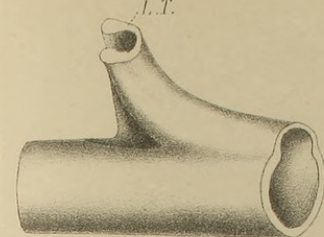

Fig. 3.

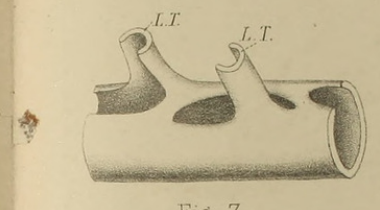

Fig. 7.

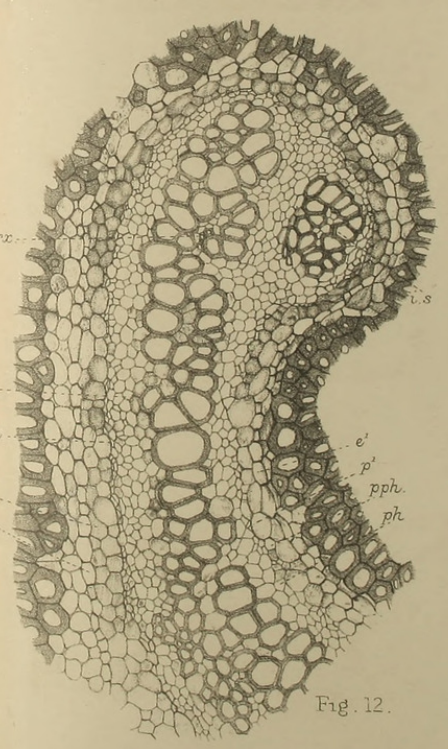

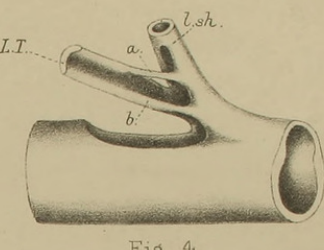
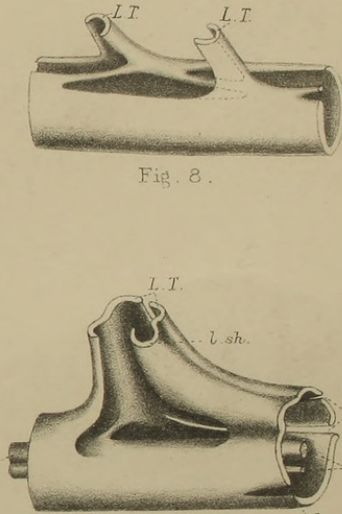

Fig 13.

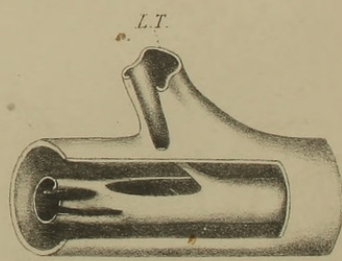

Fig. 14 


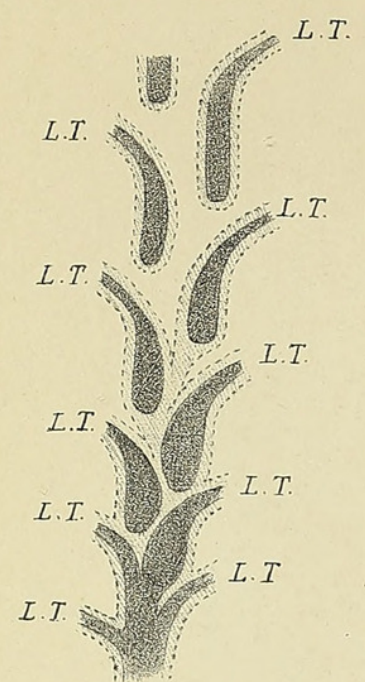

Fig. 18

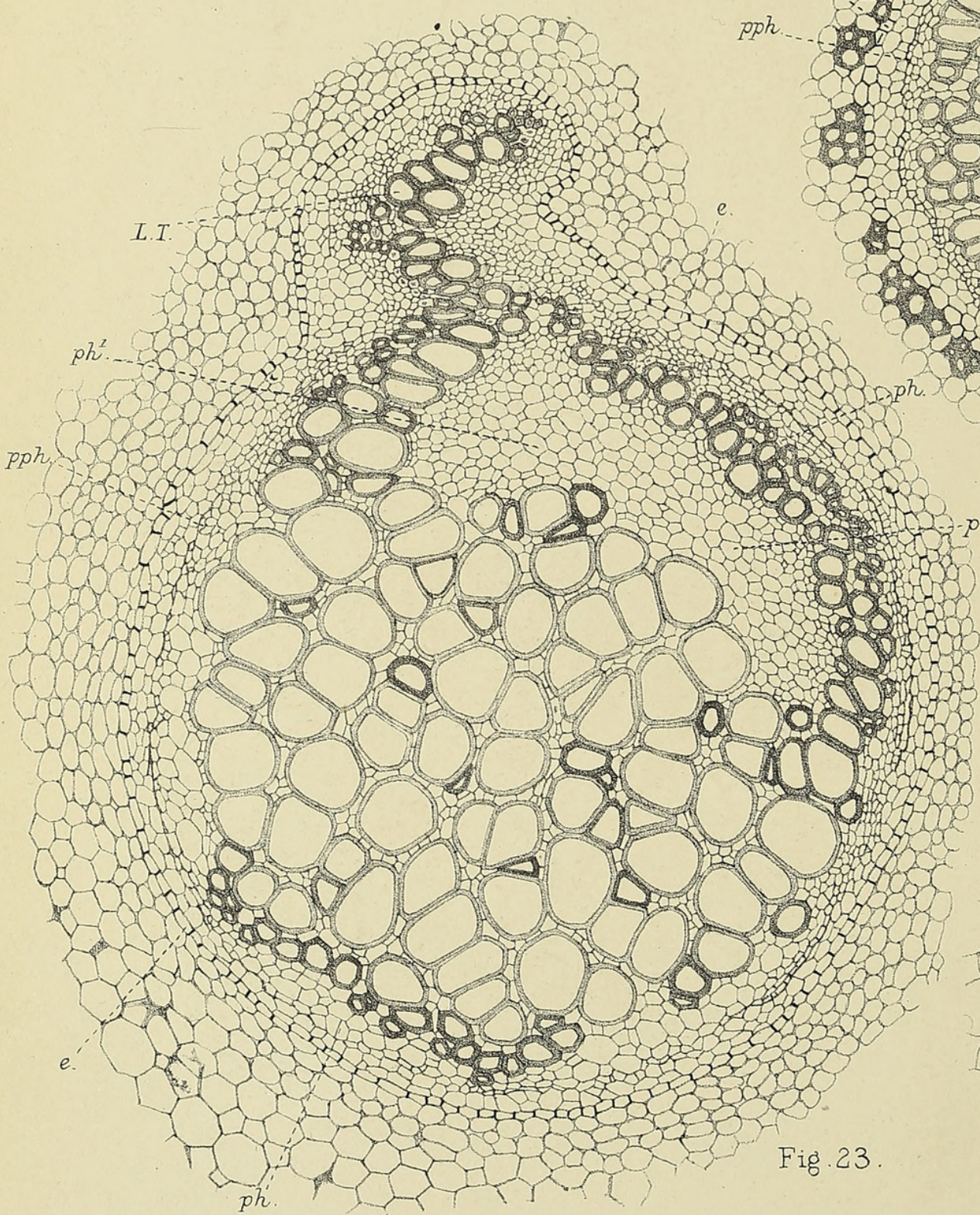

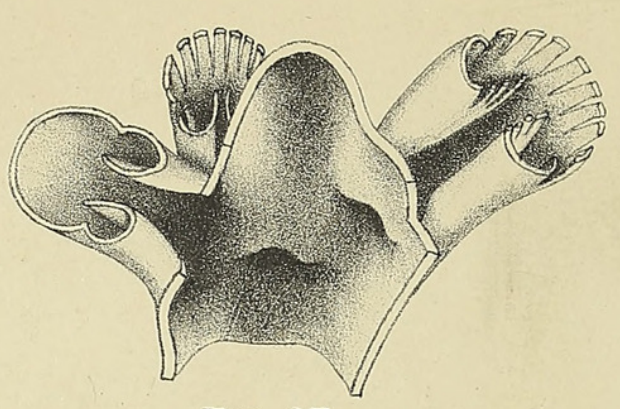

Fig. 17 .

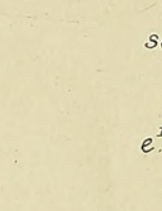

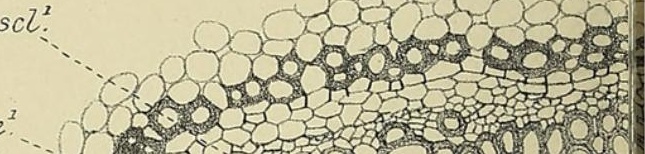

1. s. I 1930010 201 3

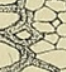

Fig. 19 $c l^{2}$ 20.8

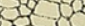
vis 35 $3,53,3$ रु

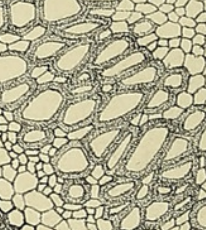
$00-1.5720$ - 100000

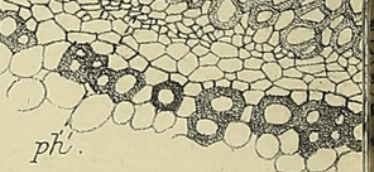
$-p \hbar^{2} . p \hbar^{2}$ a 


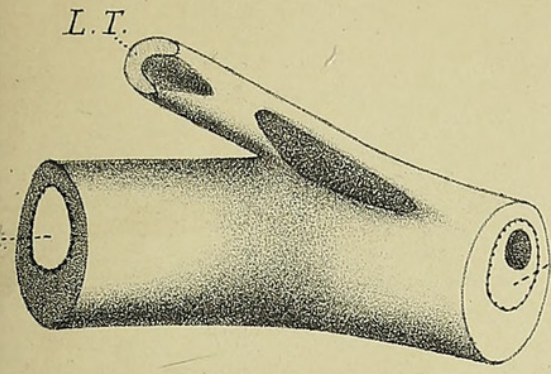

Fig. 21

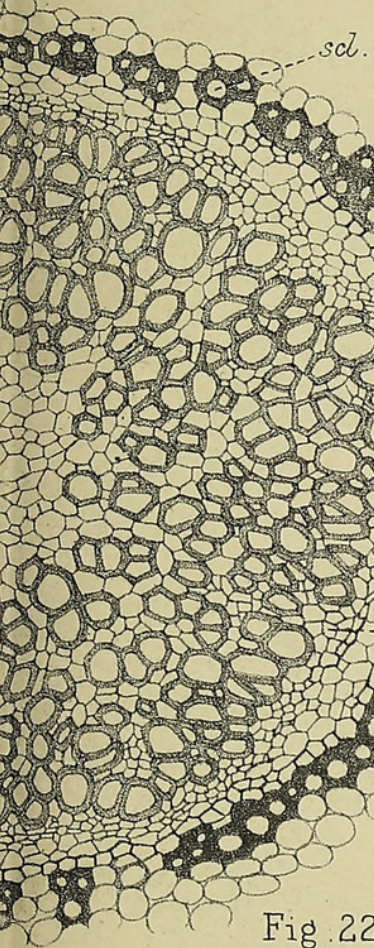

Fig.22

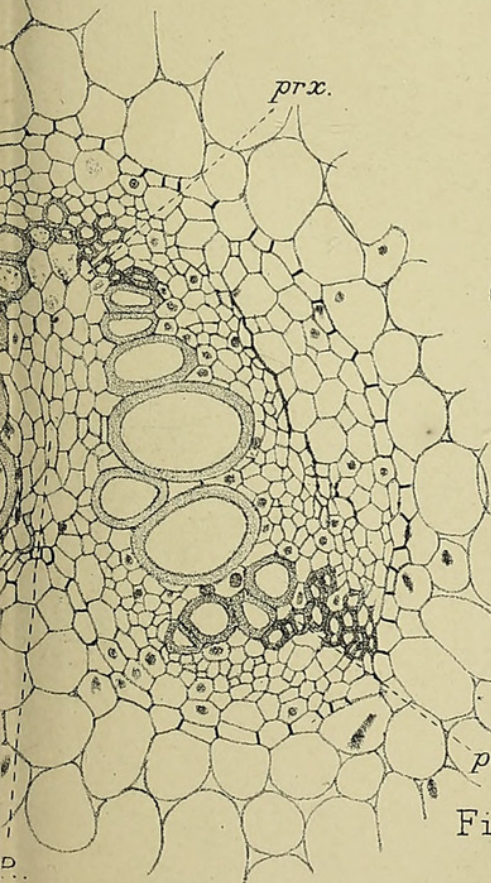

Fig.24 $p h$

$\operatorname{pr} x$

$p p h$
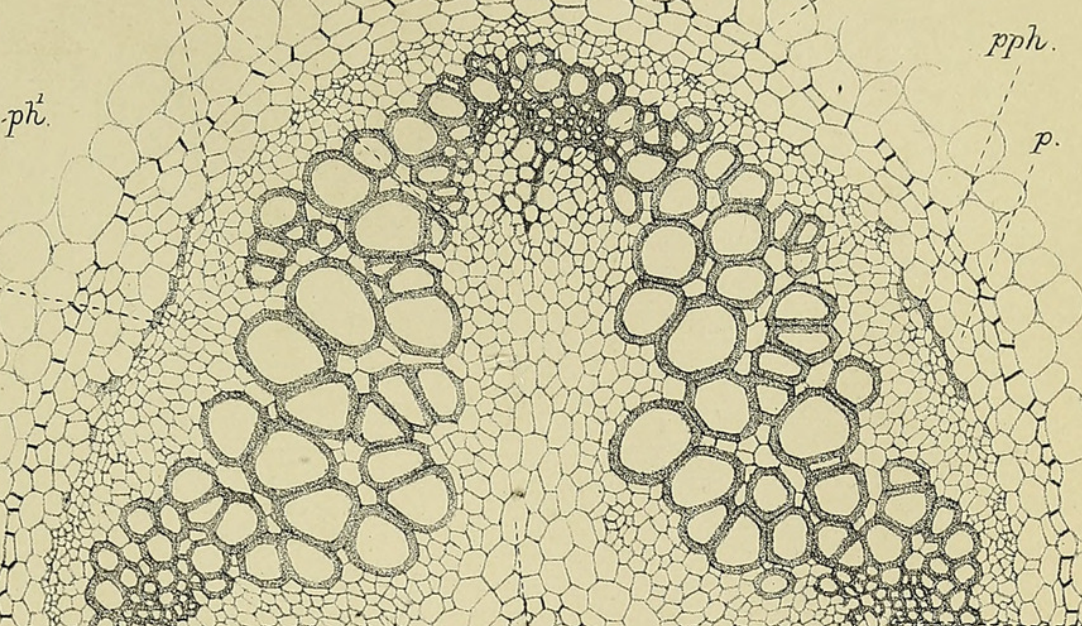

L 300 ont

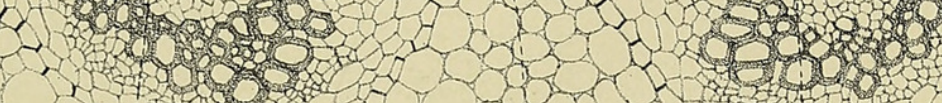

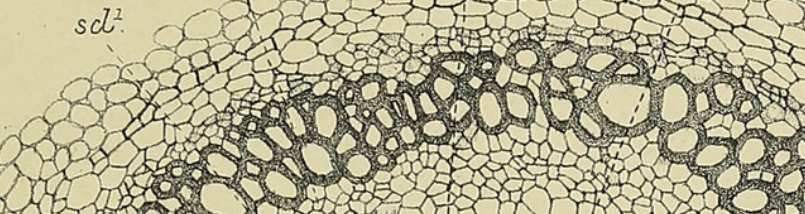
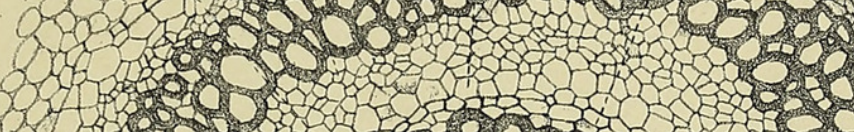

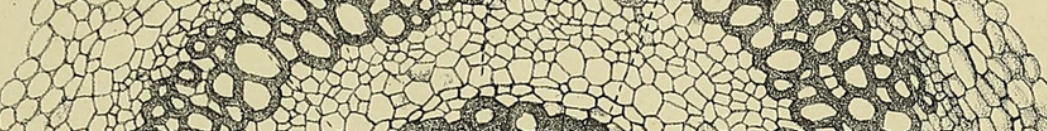
G)

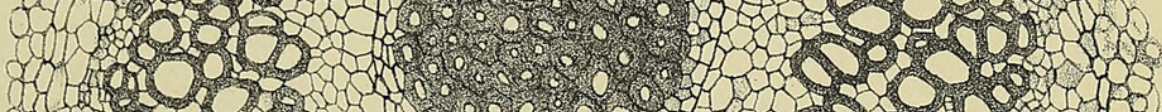

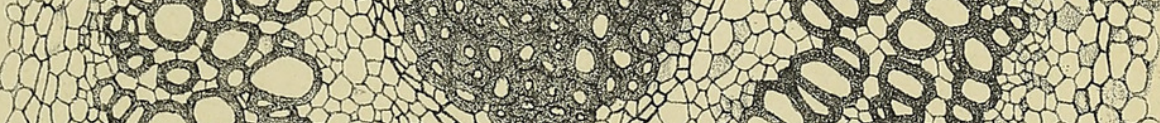

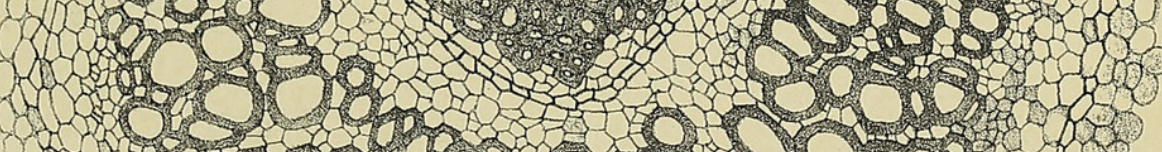

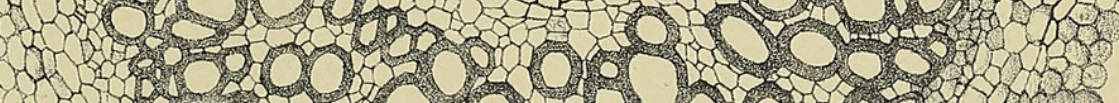

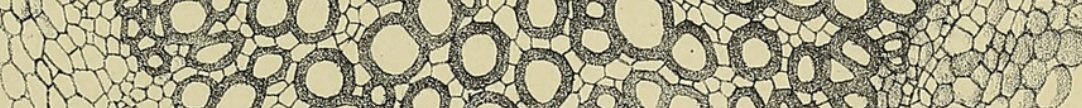

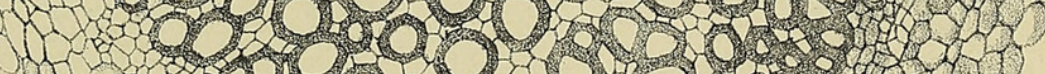

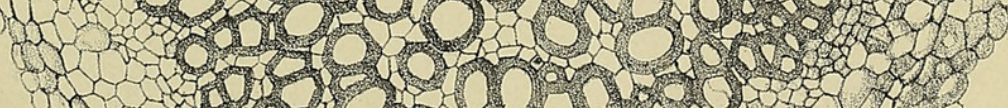

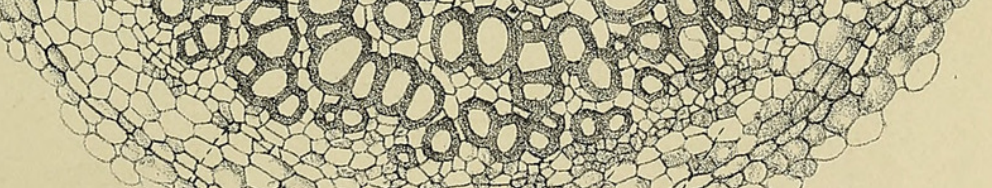

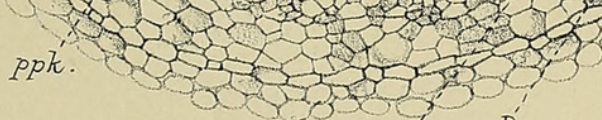
Fig. 20 

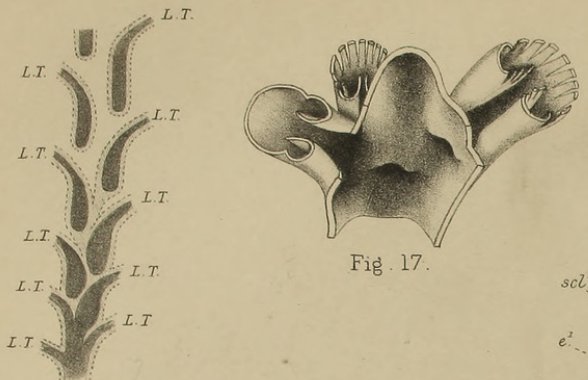

Fig. 17.

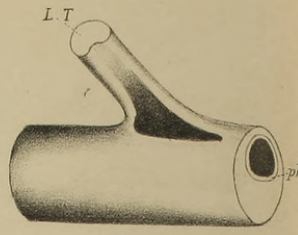

Fig. 19

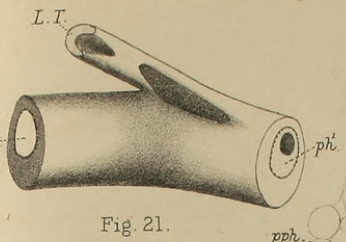

Fig. 21.

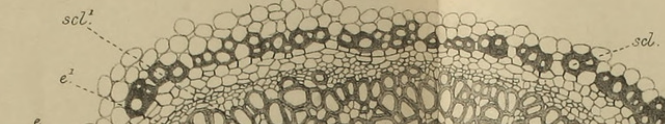

Fig. 18 .

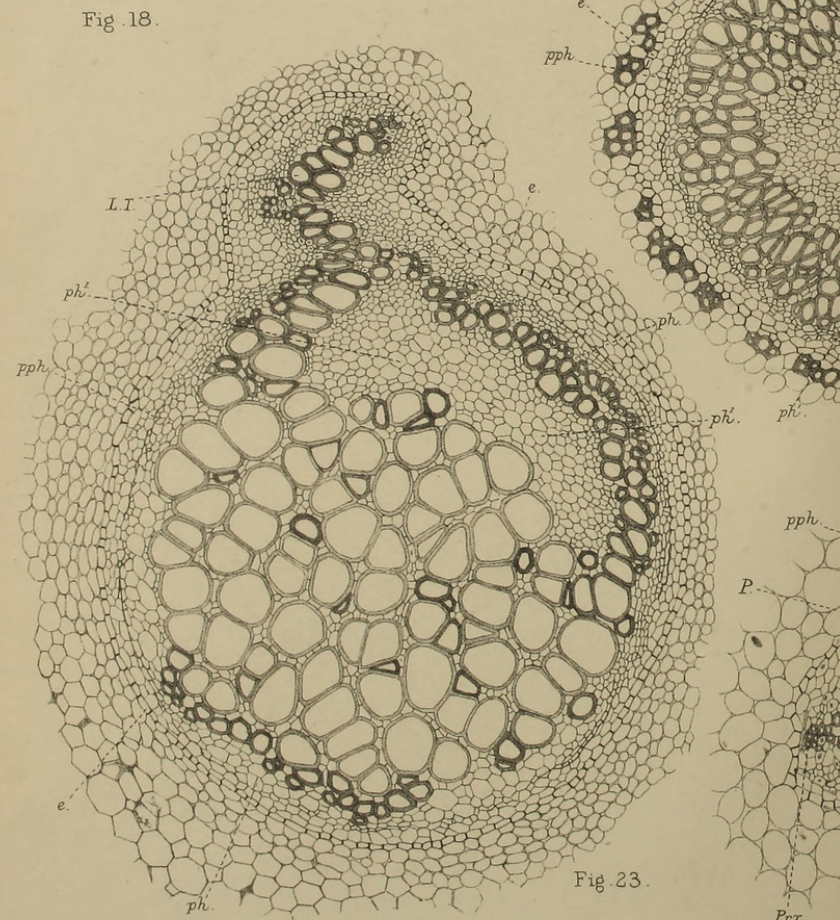

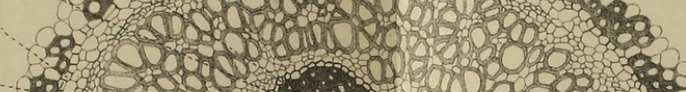

$$
\text { His: }
$$
pph w....

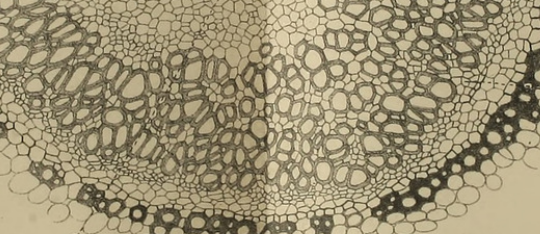
$00000.003 \% 803$

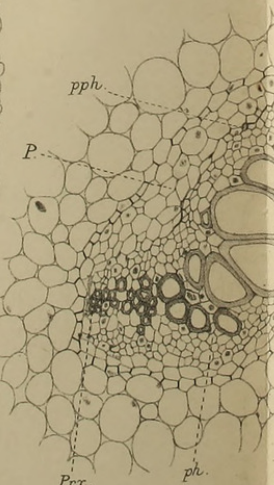
$30,0203018: 8$

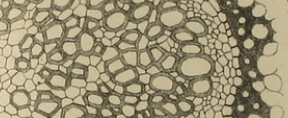
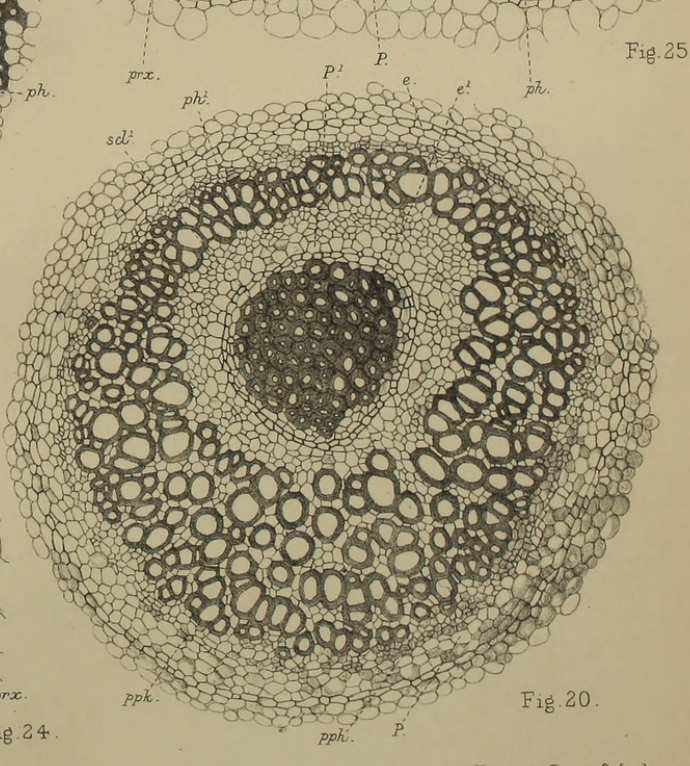


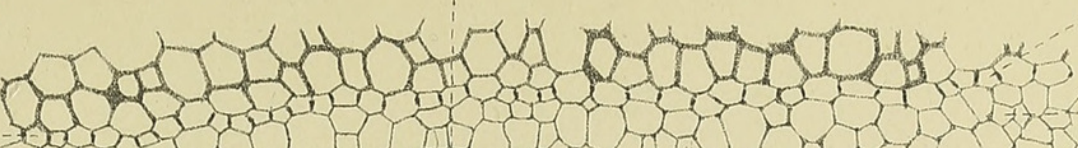
स० (1)

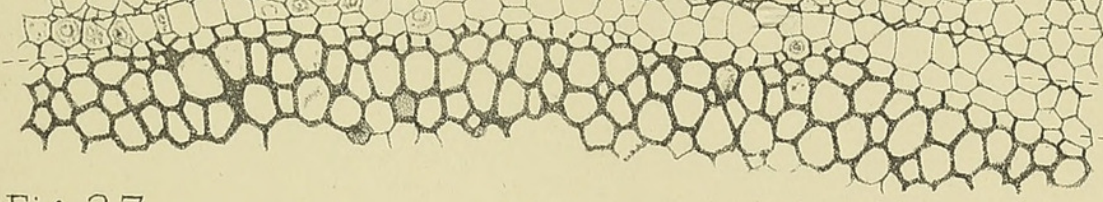
Fig. 27.

Fig. 29

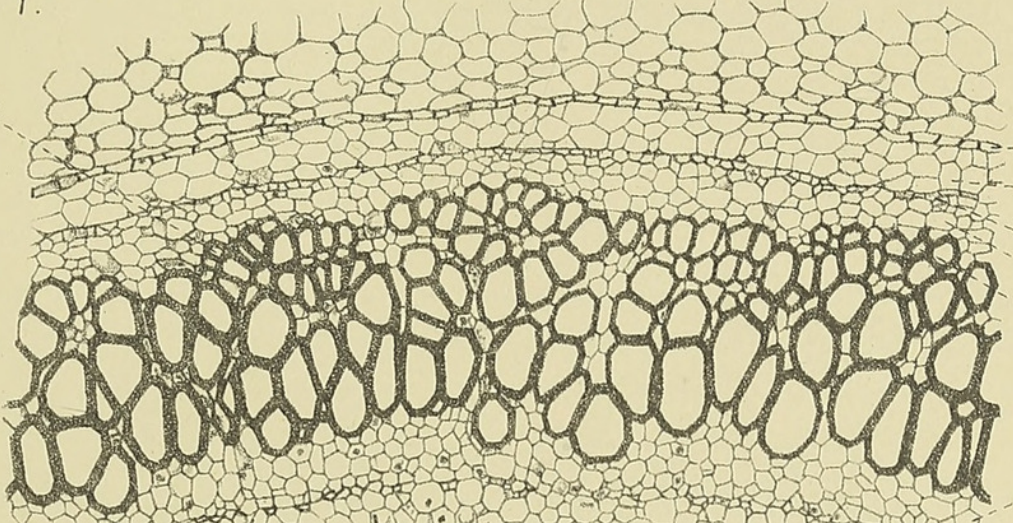

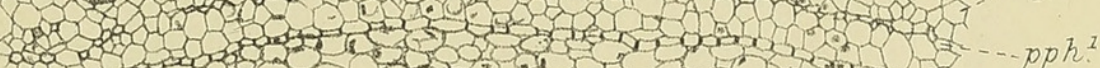

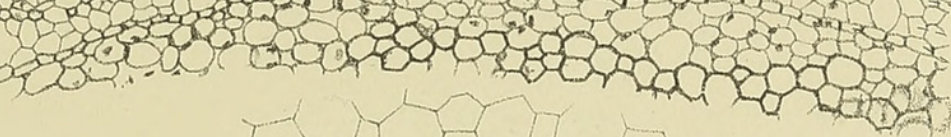

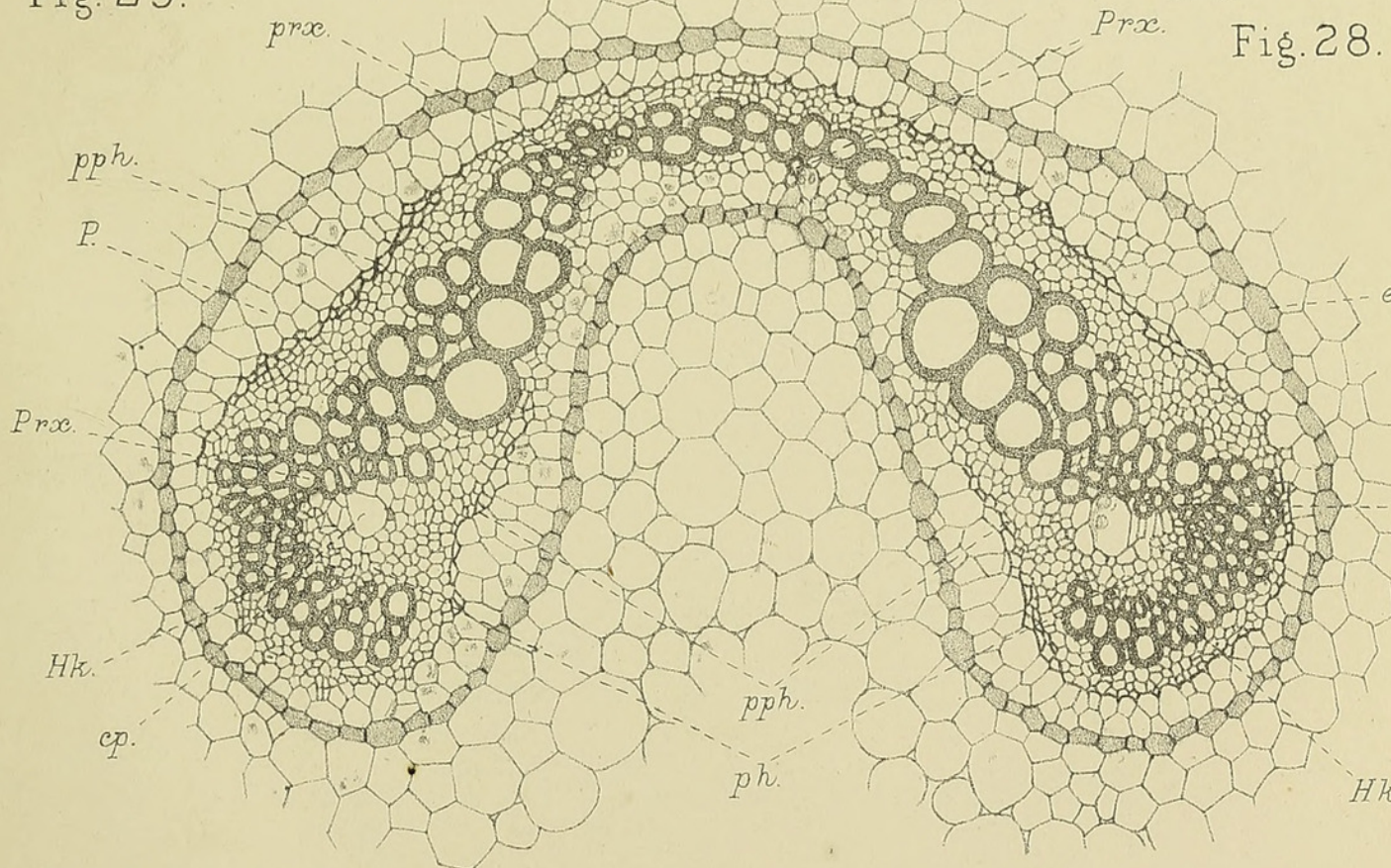




\section{$2 \mathrm{BHL}$ Biodiversity Heritage Library}

Gwynne-Vaughan, D. T. 1903. "Observations on the anatomy of solenostelic ferns. part II." Annals of botany 17, 689-742.

https://doi.org/10.1093/oxfordjournals.aob.a088940.

View This Item Online: https://www.biodiversitylibrary.org/item/235015

DOI: https://doi.org/10.1093/oxfordjournals.aob.a088940

Permalink: https://www.biodiversitylibrary.org/partpdf/318738

\section{Holding Institution}

Smithsonian Libraries

\section{Sponsored by}

Biodiversity Heritage Library

\section{Copyright \& Reuse}

Copyright Status: Not in copyright. The BHL knows of no copyright restrictions on this item.

This document was created from content at the Biodiversity Heritage Library, the world's largest open access digital library for biodiversity literature and archives. Visit BHL at https://www.biodiversitylibrary.org. 